\title{
Shaping Liquidity: On the Causal Effects of Voluntary Disclosure ${ }^{\dagger}$
}

\author{
Karthik Balakrishnan \\ Wharton School \\ University of Pennsylvania
}

\author{
Mary Billings \\ Stern School of Business \\ New York University
}

\author{
Alexander Ljungqvist \\ Stern School of Business \\ New York University \\ and NBER
}

November 2, 2011

${ }^{\dagger}$ Address for correspondence: New York University, Stern School of Business, Suite 9-160, 44 West Fourth Street, New York NY 10012-1126. Phone 212-998-0304. Fax 212-995-4220. e-mail al75@nyu.edu. 


\title{
Shaping Liquidity: \\ On the Causal Effects of Voluntary Disclosure
}

\begin{abstract}
Can managers influence the liquidity of their shares? We use plausibly exogenous variation in the supply of public information to show that firms seek to actively shape their information environments by voluntarily disclosing more information than is mandated by market regulations and that such efforts have a sizeable and beneficial effect on liquidity. Firms respond to an exogenous loss of public information by providing more timely and informative earnings guidance. Responses are greatest when firms lose local information producers and appear motivated by a desire to communicate with retail investors. Liquidity improves as a result of voluntary disclosure.
\end{abstract}

Key words: Liquidity; Voluntary disclosure; Earnings guidance; Information production; Management communication; Investor relations; Analyst coverage; Retail investors.

JEL classification: G12, G24, M41. 
Improved liquidity raises a firm's market value by lowering its discount rate (see Amihud and Mendelson (1986, 1989), Brennan and Subrahmanyam (1996), and Amihud (2002)). While liquidity is often viewed as resulting from market makers' and investors' actions in an exogenously specified information environment, we examine if corporate managers can actively influence the liquidity of their shares. An important channel through which they might do so is voluntary disclosure. Theoretical models such as Diamond (1985) and Diamond and Verrecchia (1991) show that managers may voluntarily disclose more information than is mandated by market regulations in order to reduce information asymmetry among their investors. Consistent with this, recent survey evidence suggests that managers provide voluntary disclosure to "reduce the information risk that investors assign to our stock" (Graham, Harvey, and Rajgopal (2005)).

Whether managers can indeed affect their information environments, and thereby their liquidity and cost of capital, remains an open question. The main challenge is that voluntary disclosure is voluntary: Managers choose to disclose more information for reasons that could well affect their firm's liquidity directly. For example, empirical studies suggest that firms tend to disclose more when their earnings are easier to predict (Chen, Matsumoto, and Rajgopal (2011)); but lower earnings uncertainty would reduce information asymmetry, and so increase liquidity, independently of disclosure. Thus, showing that disclosure affects liquidity causally, and by how much, has proved challenging. This endogeneity problem leads Leuz and Schrand (2009) to conclude that "the empirical evidence ... is far from conclusive."

We use plausibly exogenous variation in the supply of public information to show that firms seek to actively shape their information environments through voluntary disclosure and that such efforts improve their liquidity. The former result confirms the central assumption made in theoretical models of disclosure. The latter result contributes to our understanding of liquidity in financial markets, by showing that managers can actively influence the liquidity of their shares.

Our tests exploit a natural experiment that was first explored in Kelly and Ljungqvist (2011). 
The experiment allows us not only to investigate how managers respond to exogenous shocks to their information environments but also to show what type of investor managers are trying to communicate with and, ultimately, to establish the causal effects of their responses on liquidity.

Kelly and Ljungqvist (2011) use brokerage-firm closures to test how exogenous changes in information asymmetry affect asset pricing quantities such as stock prices and investor demands. Between Q2, 2000 and Q1, 2008, 43 brokers closed their sell-side research operations as a result of adverse changes in the economics of sell-side research. These closures resulted in 2,180 U.S. firms suffering a total of 4,429 coverage terminations. Kelly and Ljungqvist demonstrate that the closures are unrelated to individual firms' future prospects and so are plausibly exogenous at the level of the affected stocks. They then show that when a stock loses (some) analyst coverage in the wake of a brokerage closure, information asymmetry among investors increases, the firm's share price falls by $1.12 \%$ to $2.61 \%$ on announcement, and retail investors sell the stock. These patterns are most pronounced when the firm loses coverage by an analyst serving retail investors.

Our empirical approach proceeds as follows. From the intersection of Kelly and Ljungqvist's (2011) sample and the First Call 'Company Issued Guidelines' database, we identify 2,095 firms with a history of providing voluntary guidance that suffer an exogenous coverage shock between Q2, 2000 and Q1, 2008. We then create matched panels of paired stocks by first matching each 'treated' firm to an observably similar 'control' firm that did not suffer an exogenous coverage shock at the same time and retaining data for the eight quarters surrounding the termination. This set-up allows us to estimate the effect of coverage shocks using standard treatment estimators.

Our tests first replicate Kelly and Ljungqvist's (2011) finding that exogenous coverage shocks lead to an increase in Amihud's (2002) illiquidity measure (AIM), a popular liquidity proxy. We then show that the increase in illiquidity is later partially reversed, but only for firms that provide guidance: One quarter after the original shock, their illiquidity returns to near its pre-shock level on average. This reduced-form result raises the possibility that firms react to the 
reduction in analyst coverage and the resulting increase in illiquidity. In particular, we examine whether they step up disclosure in response to coverage shocks. We find that managers increase disclosure after suffering a coverage shock and do so in a sustained and informative way, especially in response to coverage shocks that had a particularly large impact on their liquidity.

It is these reversals that allow us to use lagged coverage shocks as instruments for voluntary disclosure. Identification requires that coverage shocks affect liquidity only through their effect on firms' disclosure choices and not directly. While contemporaneous shocks clearly violate the exclusion restriction, lagged shocks plausibly satisfy it. As we discuss more fully later, our results show there is no drift in the response of liquidity to coverage shocks beyond the quarter of the shock, while the reduced-form finding that liquidity recovers one quarter later is consistent with the proposed disclosure channel and not obviously consistent with any alternative channel. ${ }^{1}$

The main advantage of our identification strategy it that it isolates the effect of management actions as distinct from the confounding effects of unobserved firm characteristics. In a simple cross-sectional regression, a significant correlation between liquidity and disclosure could well reflect omitted variables. For example, high-disclosure firms tend to be less volatile, so the coefficient on disclosure might pick up the (omitted) liquidity-improving effect of lower volatility. Exogenous variation in firms' information environments allows us to sidestep this problem.

When we use lagged coverage shocks to instrument a firm's disclosure choices, we find that increased voluntary disclosure has a beneficial effect on liquidity. This suggests that managers can indeed affect their information environments through disclosure, consistent with Graham, Harvey, and Rajgopal's (2005) survey evidence. The economic effects of disclosure estimated in our IV models are between 7 and 12 times greater than when we naïvely ignore the endogenous

\footnotetext{
${ }^{1}$ We find no empirical support for the alternative hypothesis that reversals in liquidity reflect the correction of an initial overreaction among investors. Nor are reversals a feature of liquidity in the absence of coverage shocks: Using 'pseudo shocks' in the spirit of Bertrand, Duflo, and Mullainathan (2004), we find that significant reversals never occur in random data.
} 
nature of disclosure. This suggests that naïve estimates are substantially downward biased and confirms Leuz and Wysocki's (2008) conjecture that the small economic effects found in prior studies of the effect of disclosure on quantities such as liquidity or the cost of capital likely reflect endogeneity biases.

Interestingly, we find that firms respond only to the loss of a retail analyst, not when they lose coverage by an analyst catering exclusively to institutional investors. This suggests that managers supply guidance primarily with the aim to reduce information asymmetry (and thereby increase share price) by communicating with retail investors. This is consistent with asymmetricinformation asset pricing models in which retail investors possess a subset of the information held by institutional investors; see for example Easley and O’Hara (2004). In such models, reducing information asymmetry increases prices.

Besides introducing exogenous variation into this literature, our research design departs from prior empirical work in three main ways. First, we focus on a discretionary action, namely the extent to which managers provide guidance regarding their quarterly EPS numbers, the most prominent summary performance measure that a firm supplies to its investors. Prior work instead focuses on external ratings of a firm's disclosure policy from the AIMR database (see Lang and Lundholm (1993, 1996), Botosan and Plumlee (2002), and Brown and Hillegeist (2007)); the frequency of 8-K filings (Leuz and Schrand (2009)); the length of the Management Discussion and Analysis section in 10-K filings (Leuz and Schrand (2009)); or self-constructed measures of disclosure (Botosan (1997)). Such tests likely have lower power because it is unclear how much immediate discretion managers have over their financial statements, given accounting standards, mandatory disclosure requirements, and scrutiny by their auditors.

Second, our sample period begins at the time Regulation Fair Disclosure came into effect. Reg FD prohibits firms from selectively disclosing information to investors or analysts. As Leuz and Wysocki (2008) note, "Reg FD may have changed the degree of information asymmetry 
between investors. At the same time, it may have changed firms' incentives to provide information to the markets in the first place." Prior studies examining the influence of disclosure on firms' information environments largely use pre-Reg FD data (see Coller and Yohn (1997), Botosan and Plumlee (2002), and Brown and Hillegeist (2007)).

Third, we exploit cross-sectional variation in disclosure content. Prior work on guidance focuses on its quantity (Anantharaman and Zhang (2011), Li (2011)) or frequency (Fu, Kraft, and Zhang (2011), Leuz and Schrand (2009)). We show that content matters. In particular, only certain types of guidance - forecasts rather than pre-announcements, quantitative rather than qualitative, negative rather than positive or uninformative - affect liquidity.

Two related papers are worth discussing in more detail. Leuz and Schrand (2009) use the Enron scandal as a one-off exogenous shock to firms' costs of capital and show that it induces managers to increase both the length of their annual 10-K filings and the frequency of their interim 8-K disclosures. Anantharaman and Zhang (2011) decompose variation in analyst coverage into an explained and an unexplained part (albeit without an instrument) and show that firms increase the volume of earnings guidance following unexplained drops in analyst coverage. Our paper, in contrast, isolates a causal link between disclosure and liquidity, and does so using a sequence of staggered exogenous shocks to firms' information environments.

Our study makes three main contributions. First, prior literature has been unable to identify an economically meaningful benefit to voluntary disclosure. Once we correct for endogeneity, we find that firms can affect the liquidity of their shares substantially through voluntary disclosure. Since greater liquidity leads to a lower cost of capital, this implies that voluntary disclosure can increase a firm's value. While not unexpected, given the survey evidence reported in Graham, Harvey, and Rajgopal (2005), quantifying the liquidity effect is nonetheless important given companies' legitimate concerns that voluntary disclosure could benefit their product-market competitors (Campbell (1979), Bhattacharya and Ritter (1983)) or result in 
shareholder lawsuits (Skinner (1994), Francis, Philbrick and Schipper (1994)).

Second, we contribute to an active debate among practitioners and academics as to whether guidance is desirable. Consultants such as McKinsey ${ }^{2}$ and Deloitte ${ }^{3}$ and influential institutions such as the Business Roundtable and the CFA Institute ${ }^{4}$ advise against the practice, citing legal costs, 'punishment' by investors for missed earnings, and lack of evidence that disclosure raises stock prices or mitigates volatility. Early economic models viewed disclosure negatively. Hirshleifer (1971), Trueman (1973), and Hakansson, Kunkel, and Ohlsen (1982) show that disclosure can reduce investors' ability to share risk. Fama and Laffer (1971) and Hakansson (1977), on the other hand, argue it can raise firm value by lowering investors' information acquisition costs. Later work by Diamond (1985) shows that disclosure can in fact improve risksharing in a general-equilibrium setting, while Fishman and Hagerty (1989) argue that disclosure improves stock price efficiency and thereby leads to more efficient managerial investment decisions. Our analysis speaks directly to the beneficial effect of disclosure on stock liquidity.

Third, we present novel evidence suggesting that voluntary disclosure is primarily aimed at reducing information asymmetries between retail and institutional investors. This new stylized fact is consistent with asset pricing models that stress the importance of information asymmetries for investor demands and hence asset prices.

The paper proceeds as follows. Section 1 describes our sample. Section 2 outlines the empirical strategy. Section 3 prepares the grounds for our identification strategy by showing that exogenous coverage shocks have a large adverse effect on liquidity which subsequently reverses. Section 4 investigates whether the reversals reflect management efforts to fill information gaps, left by coverage shocks, through increased voluntary disclosure. Section 5 reports instrumentalvariables regressions that model the causal effect of disclosure on liquidity. Section 6 concludes.

\footnotetext{
${ }^{2}$ See Hsieh, Koller, and Rajan (2006).

${ }^{3}$ See http://www.corpgov.deloitte.com/site/caneng/financial-reporting/transparency/earnings-guidance.

${ }^{4}$ Quoted in Houston, Lev, and Tucker (2007).
} 


\section{Sample and Data}

Our sample combines data from CRSP, Compustat, and I/B/E/S with data from First Call's ‘Company Issued Guidelines' (CIG) database. We begin by constructing an unbalanced panel of all firms in the CRSP-Compustat merged file for the period 1999 through 2009. Following Coller and Yohn (1997), we focus on quarterly guidance. The unit of observation in all our tests is a firm-fiscal quarter. For every firm-fiscal quarter, we retrieve all instances of quarterly guidance from First Call; analyst coverage information from I/B/E/S; market capitalization and return volatility from CRSP; and equity issuance and fiscal year-end data from Compustat. We also compute, for every firm-fiscal quarter, two popular proxies for liquidity: Amihud's (2002) illiquidity measure $(A I M)$, which measures the price impact of trades, and bid-ask spreads. For full details of the construction of all our variables, see Appendix A.

From this panel, we extract a treatment sample of firms that suffer exogenous coverage terminations and thus shocks to their information environments. We compare the guidance behavior and liquidity dynamics of these treated firms to a control sample composed of matched firms that do not suffer exogenous shocks to their analyst coverage. This approach allows us to difference away secular trends and swings in liquidity. Figure 1 shows that market-wide illiquidity generally trended down, beginning in late 2002, and rose sharply in the wake of the collapse of Lehman Brothers on September 15, 2008.

Kelly and Ljungqvist (2011) document that the coverage shocks we use are plausibly exogenous, so we do not need to worry about unobserved heterogeneity, selection, or endogeneity contaminating our tests. All that remains is to make sure that treated and control firms are observably similar and hence comparable.

\subsection{Treatment Sample}

Kelly and Ljungqvist (2011) identify a sample of 2,180 unique firms suffering 4,429 exogenous coverage terminations as a result of 43 brokerage closures over the period Q2, 2000 
through Q1, 2008. Kelly and Ljungqvist's unit of analysis is a firm-day. As mentioned, we focus instead on firm-fiscal quarters. Some of Kelly and Ljungqvist's firms are hit with multiple coverage shocks in a given fiscal quarter, leaving 4,185 firm-fiscal quarters with one or more termination events.

To assemble our treatment sample, we impose three filters, as set out in Table 1. First, we remove 1,122 firm-fiscal quarters involving 737 firms that had no history of providing guidance as of the termination quarter (according to First Call). Dropping such firms means we focus on within-firm changes in guidance policy (i.e., the intensive margin). ${ }^{5}$ Second, we require that a treated firm has suffered no exogenous coverage terminations in the previous four quarters. This requirement eliminates 794 firm-fiscal quarters involving 447 'serially shocked' firms and ensures that we observe a clean treatment effect uncontaminated by the accumulation of recent coverage shocks. Third, since our tests are in the spirit of diff-in-diffs, we remove four instances of firms that did not trade in the quarter before a termination and two firms that lost coverage in their last fiscal quarter of listing on the NYSE, Amex, or Nasdaq. These filters yield 2,263 termination quarters for which we next seek to identify observably similar control firms.

\subsection{Control Firms}

Kelly and Ljungqvist (2011) document that firms suffering exogenous coverage terminations have significantly larger market capitalizations, are covered by significantly more analysts, and have significantly more volatile stock returns than the average firm in CRSP and I/B/E/S. ${ }^{6}$ Firm size, analyst coverage, and volatility have previously been shown to correlate with liquidity (see Breen, Hodrick, and Korajczyk (2002), Irvine (2003), and Chordia, Roll, and Subrahmanyam (2000), respectively). Thus, to ensure that our test results are not confounded by these systematic

\footnotetext{
${ }^{5}$ The extensive margin (initiation of a guidance program) is also of potential interest. However, only 57 firms provide guidance for the first time in the first fiscal quarter after an exogenous coverage termination, so firms do not appear to respond to loss of coverage by initiating guidance for the first time. We will return to this point below in the context of a 'placebo' test.

${ }^{6}$ This partly reflects the fact that analysts tend to cover larger firms. Thus, larger firms (which are covered by more analysts) are more often affected by brokerage closures than smaller firms (which are covered by fewer analysts).
} 
differences, we match firms on these characteristics. In addition, given our focus on liquidity, we also match on the Amihud illiquidity measure (AIM).

Specifically, for each treated firm, we identify the stock that is closest to the treated firm in terms of log market value of equity, the number of analysts covering the stock, return volatility, and AIM, all measured in the fiscal quarter before the treated firm's coverage termination.

Mirroring the filter imposed on the treatment sample, we also require that a potential match has not itself suffered an exogenous coverage termination in the previous four quarters. ${ }^{7}$ The match is implemented using a nearest-neighbor propensity score match without replacement.

Of the 2,263 treated firm-fiscal quarters, 168 cannot be matched to any eligible control firm within standard tolerances (specifically, a 0.005 caliper). The final treatment sample therefore consists of 2,095 firm-fiscal quarters with one or more exogenous coverage termination events affecting 1,468 unique firms and a corresponding sample of 2,095 controls matched on firm characteristics measured in the fiscal quarter before the termination.

\subsection{Panel-Regression Sample}

For the purposes of our tests, we retain (up to) four quarters before and (up to) four quarters after each of the 2,095 termination quarters for both treated firms and their matched controls. We refer to these nine-quarter spans as termination episodes. In total, the estimation sample used in our panel-regression tests consists of 17,017 firm-fiscal quarters for treated firms and 17,239 firms-fiscal quarters for their controls. ${ }^{8}$

To avoid look-ahead bias, our filters allow firms to suffer further exogenous shocks to their analyst coverage in the four quarters after the initial termination quarter. Such further shocks occur in 592 post-termination quarters, bringing the total number of affected quarters to 2,687 (=

\footnotetext{
${ }^{7}$ In addition, mirroring the other filters we impose on treated firms, we require that control firms are already guiders and trade in both the quarter before and the quarter after a treated firm's coverage termination. As in Kelly and Ljungqvist (2011), both treated and control firms are required to be operating companies (CRSP share codes $\leq 12$ ).

${ }^{8}$ Recall that we require firms not to have suffered an exogenous coverage termination in the four fiscal quarters before entering our sample. This ensures that none of the 2,095 termination episodes overlaps in time for the same firm and so each treated firm-fiscal quarter is present in the panel-regression sample at most once.
} 
2,095 + 592). Bearing in mind that some firms suffer multiple shocks in a given fiscal quarter, the overall number of coverage shocks captured in our panel-regression sample is 2,821 , or $63.7 \%$ of the 4,429 coverage shocks in Kelly and Ljungqvist's (2011) sample. ${ }^{9}$

\subsection{Descriptive Statistics}

Table 2 shows how tightly matched treated and control firms are. Panel A reports summary statistics for the four variables we match on, measured as of the fiscal quarter before a termination, along with differences in means and medians between the two groups of firms. Market capitalization averages $\$ 7,861$ million for treated firms and $\$ 7,919$ million for controls. The average treated firm is covered by 6.9 analysts pre-termination, compared to an average of 7 analysts among the controls. Average monthly return volatility is $3.2 \%$ for treated firms and $3.3 \%$ for controls. And finally, the log Amihud illiquidity measure averages 0.049 for both groups. None of these differences in means is statistically significant at even the $10 \%$ level. The same is true of the medians, which are similarly close.

Panel B reports eight measures of voluntary disclosure. At the broadest level, 33.4\% of treated firms and $31.9 \%$ of the controls provide some kind of management guidance in the quarter preceding an exogenous coverage termination. The literature distinguishes between two guidance horizons: Management forecasts (defined as guidance issued before the end of the fiscal quarter) and earnings pre-announcements (defined as guidance issued after the end of the fiscal quarter but before actual earnings are announced). Forecasts are more common than preannouncements in our data: $27.5 \%$ of treated firms and $26.7 \%$ of the controls provide forecasts while $9.4 \%$ of treated firms and $8.3 \%$ of the controls pre-announce. None of the differences between treated and control firms is significant.

Our data allow us to distinguish between different types of guidance based on their form and

\footnotetext{
${ }^{9}$ Non-guiders account for 1,174 of the 1,608 Kelly-Ljungqvist coverage shocks that do not make it into our sample. The remainder comes mostly from serially shocked firms.
} 
content. There are two forms of guidance. It can be quantitative in nature (providing at least one numerical earnings forecast or a forecast range); or it can be qualitative in nature (to the effect that earnings are forecast to be above, below, or in line with expectations without providing a numerical estimate). Consistent with Anilowski, Feng, and Skinner (2007), we find that quantitative guidance is more common: It is provided by around $30 \%$ of firms, compared to around $5 \%$ of firms that provide qualitative guidance. There are no significant differences between treated and control firms in these proportions.

We distinguish three types of content: Negative, positive, and 'hot air.' We code guidance as negative (positive) if management supplies an earnings estimate that falls below (exceeds) the prevailing consensus (i.e., the median analyst forecast) one day before the guidance date. We code the remaining guidance as 'hot air,' which captures cases where management supplies guidance that does not differ from the prevailing consensus. Negative guidance is around twice as likely as positive guidance (about $18 \%$ versus $9 \%$ ). This is broadly consistent with Anilowski, Feng, and Skinner (2007). Around 7\% of firms provide guidance that amounts to hot air. As is the case for the other variables reported in Table 2, treated and control firms do not differ significantly in the content of their guidance.

To provide a broader context for these patterns, Figure 2 shows trends in quarterly guidance in First Call's CIG database going back to 1998, the year First Call began to systematically collect management guidance (Anilowski, Feng, and Skinner (2007)). The top left chart neatly illustrates the large impact of the SEC's Regulation Fair Disclosure, which came into effect on October 23, 2000. The quarterly number of pieces of guidance increased from 735 in Q3, 2000 to 1,132 in Q4, 2000 and 1,566 in Q1, 2001, consistent with firms shifting from a private to a public channel of communication with the market. Since then guidance has trended downwards. In Q3, 2010, the last quarter for which guidance data is available, firms issued 588 pieces of guidance according to First Call. The remaining three graphs in Figure 2 provide breakdowns of 
voluntary guidance by horizon, form, and content. They show that forecasts are more numerous than pre-announcements, that guidance is increasingly (and now virtually exclusively) quantitative in nature, and that negative guidance outnumbers positive guidance around two-toone. These patterns mirror those we see in our sample.

\section{Empirical Strategy}

We begin by replicating, in our sample, Kelly and Ljungqvist's (2011) finding that exogenous coverage terminations in quarter $t=0$ are associated with a sizeable and significant increase in illiquidity, both absolutely and relative to their matched controls. It is these shocks to firms' information environments that we propose to exploit for identification purposes.

We next show that illiquidity decreases again one quarter later, at $t=+1$. We investigate the possibility that this dynamic reflects simple mean reversion due to investor overreaction.

Evidence from a set of 'pseudo shocks' and separate results from a set of 'placebo' firms suggest that overreaction is an unlikely explanation. Instead, we conjecture that the post-shock decrease in illiquidity reflects firms' efforts to fill the information gap created by the loss of coverage.

In Section 4, we test this conjecture by showing that firms increase their voluntary disclosure in response to coverage shocks; that these increases are sustained for a period of one year; that firms focus on providing informative guidance; and that voluntary disclosure is particularly responsive to the loss of local and/or retail analysts and to coverage shocks that had a large impact on the firm's liquidity. Collectively, these patterns suggest that exogenous coverage terminations have the potential to be a useful and valid instrument for voluntary disclosure.

Validity requires not only that coverage shocks be correlated with voluntary disclosure but also that they be uncorrelated with liquidity (other than indirectly through their effect on disclosure). This exclusion restriction is seemingly violated by the fact that coverage shocks do increase illiquidity significantly. This rules contemporaneous coverage shocks out as instruments. Lagged shocks, however, satisfy the exclusion restriction: As mentioned, liquidity 
improves again in the quarter following a coverage termination. This reduced-form relation is consistent with the proposed disclosure channel. It also imposes a testable restriction on the correlation between disclosure and liquidity: For our identification strategy to be plausible, firms' disclosure choices should affect liquidity only when lagged, not contemporaneously, and we confirm this in naïve regressions of liquidity on disclosure.

In summary, the data suggest the following timeline of events. In quarter $t=0$, a firm suffers an exogenous shock to its information environment. Investors react instantly to the increased information asymmetry by reducing the firm's liquidity in the same quarter. The firm responds by increasing its voluntary disclosure for a period of four quarters beginning in quarter $t=0$. In quarter $t=+1$, investors react to the increased disclosure and the firm's liquidity improves.

In Section 5 , we test this timeline by regressing liquidity in quarter $t=+1$ on the firm's disclosure choices dated $t=0$, which we in turn instrument using coverage shocks dated $t=-3$ to $t=0$. This instrumental variables regression provides an estimate of the causal effect of a firm's voluntary disclosure on its liquidity.

\section{The Effect of Coverage Shocks on Liquidity}

\subsection{Difference-in-Differences Test}

Kelly and Ljungqvist (2011) perform a difference-in-differences test which compares changes in Amihud's (2002) illiquidity measure from the three months before a coverage termination day to the three months after for treated firms and a set of control firms matched on pre-event size, book-to-market, and liquidity. Our matching criteria are somewhat different from theirs, ${ }^{10}$ as is our unit of time (fiscal quarters rather than event time), and as a result of filtering out non-guiders and serially shocked firms, our treatment sample is a subset of theirs.

\footnotetext{
${ }^{10}$ Kelly and Ljungqvist (2011) focus on the asset pricing implications of shocks to information asymmetry and thus match on size, book-to-market, and liquidity, three of the most common asset pricing factors. Our focus instead is on liquidity per se. As mentioned earlier, liquidity has been linked to size, volatility, and analyst coverage, so our matching criteria are designed to hold these characteristics constant between the treatment and control samples.
} 
As Table 3 shows, these sampling differences do not affect the results. Like Kelly and Ljungqvist (2011), we observe sizeable and significant increases in log AIM following coverage terminations. In the sample of 2,095 treated firms, illiquidity increases by an average of 0.024 from the prior-quarter average of 0.049 . The 2,095 control firms also see their illiquidity increase, though by less: Their change averages $0.014{ }^{11}$ The difference-in-differences of 0.010 is both economically large and statistically significant (at the 0.033 level) based on bootstrapped standard errors stratified by fiscal quarter. ${ }^{12}$ It is a third smaller than the 0.015 diff-in-diff Kelly and Ljungqvist report. This is due to the fact that we exclude non-guiders. Non-guiders' liquidity is more sensitive to coverage shocks, in part because they are covered by significantly fewer analysts to begin with (4.8 versus 6.9 , on average).

\subsection{Conditional Treatment Effect}

Table 4, column 1 estimates the conditional treatment effect in the context of a least-squares panel regression with firm fixed effects. We regress $\log A I M$ on an indicator for firms suffering a coverage shock (capturing the treatment effect) and three lagged covariates that prior literature has linked to liquidity: Log market cap, the log number of analysts covering the stock, and return volatility. We also include an indicator for firms that are net equity issuers; ${ }^{13}$; fiscal-quarter fixed effects to control for possible seasonalities in a firm's information environment over the course of its fiscal year; and year effects.

Conditioning on within-firm variation in characteristics leads to a small attenuation in the treatment effect, which declines from 0.010 in the unconditional diff-in-diff to 0.008 in the regression specification. The effect is statistically significant, regardless of the assumptions we make about the variance-covariance matrix. Column 1 clusters the standard errors by firm, which

\footnotetext{
${ }^{11}$ The fact that control firms experience non-zero changes in AIM reflects secular trends and swings in liquidity and illustrates the need to perform diff-in-diff tests. See Kelly and Ljungqvist (2011) for further discussion.

${ }^{12}$ Bootstrapping adjusts for potential cross-sectional dependence due to time clustering as multiple stocks are terminated in each of the 43 brokerage-firm closures.

${ }^{13}$ While equity issuance is not an obvious determinant of liquidity, Lang and Lundholm (1993) show that net equity issuers have reason to provide more voluntary disclosure.
} 
yields a $p$-value of 0.002 . Column 2 instead bootstraps the standard errors stratified by quarter, which yields a marginally higher $p$-value of 0.004 .

To validate these $p$-values, we follow Bertrand, Duflo, and Mullainathan (2004). Specifically, we randomly generate 1,000 sets of 4,185 'pseudo coverage shocks', filter the observations as in Table 1, create matched control samples, and estimate the column 1 model. This yields 1,000 estimates of the effect of made-up (rather than actual) 'shocks' on liquidity. The empirical probability of observing a coefficient as large as 0.008 in these random data is 0.044 (44 out of the 1,000 trials). This suggests that the clustered standard errors in columns 1 and 2 are downward biased, but not by enough to falsely reject the null of no (real) effect at the $5 \%$ level.

The other coefficients in column 1 confirm that larger firms and firms covered by more analysts are significantly more liquid, consistent with prior work, as are net equity issuers. Volatility correlates positively with illiquidity but this effect is not statistically significant.

In sum, these results confirm Kelly and Ljungqvist's (2011) finding that exogenous coverage terminations have a first-order adverse effect on liquidity as investors react to the increase in information asymmetry that results from the loss of public analyst signals.

\subsection{Dynamics}

Column 3 of Table 4 adds three lags of the coverage-shock indicator to the AIM regression. Among these, only shocks dated $t=-1$ are statistically significant $(p=0.004)$ and their effect on illiquidity is a negative, with a coefficient of $-0.009 .{ }^{14}$ Thus, the contemporaneous increase in illiquidity due to coverage shocks at $t=0$ appears to be partially reversed during the next fiscal quarter. This novel finding, which extends the analysis in Kelly and Ljungqvist (2011), suggests that the effect of exogenous coverage terminations on liquidity is to some extent transitory. Lags

\footnotetext{
${ }^{14}$ In our 1,000 trials using randomly generated 'pseudo coverage shocks', the empirical probability of observing a coefficient as large (in absolute terms) as -0.009 is 0.02 ( 20 out of 1,000 trials).
} 
dated $t=-2$ and $t=-3$ are neither economically nor statistically significant, so the adjustment process appears to be completed within one fiscal quarter.

What could explain these liquidity reversals? They could of course simply be random, but using our 1,000 trials of randomly generated 'pseudo coverage shocks', we never see a significant increase in AIM being followed by a significant decrease (or vice versa). Reversals of the kind found in Table 4 thus do not appear to happen randomly. Instead, we conjecture that the improvement in liquidity we observe following (real) coverage shocks reflects firms' efforts to fill the information gap created by their loss of analyst coverage. The leading alternative explanation is that investors initially overreact to the loss of coverage and arbitrage processes subsequently restore liquidity, resulting in mean reversion. We now turn to cross-sectional and placebo tests to discriminate between these explanations.

\subsection{Cross-Sectional and Placebo Tests}

We first exploit cross-sectional variation in the number of exogenous coverage shocks a firm suffers in a quarter. As Table 1 shows, there are 118 firms with two and eight firms with three shocks per quarter. If the post-shock decrease in illiquidity reflects firms' reactions to the loss of analyst coverage, we expect a stronger reaction among firms that suffer multiple coverage shocks in a quarter. Column 4 of Table 4 tests this prediction by adding two indicator variables set equal to 1 if a firm suffered multiple coverage shocks in quarters $t=0$ or $t=-1$. These measure the marginal impact of multiple shocks, relative to single shocks, on AIM.

The contemporaneous coefficient estimate of 0.001 for multiple shocks is practically zero $(p=0.812)$. Thus, the contemporaneous effect of single and multiple shocks on liquidity is statistically the same, suggesting that investors' responses to increases in information asymmetry do not vary with the number of lost signals in the cross-section. Multiple shocks are, on the other hand, followed by significantly larger liquidity improvements one quarter later compared to single shocks. The coefficient estimate for the differential impact between multiple and single 
shocks is -0.023 . This is economically large compared to the single-shock coefficient of -0.008 and highly statistically significant $(p=0.001)$.

These findings are not obviously reconcilable with a simple overreaction story. If the dynamic pattern in liquidity around coverage terminations were caused by investors initially (and temporarily) overreacting to a loss of coverage, why would the overreaction not increase in the number of signals lost while the subsequent 'correction' would? A more plausible interpretation, in our view, is that management appears to react more strongly to larger shocks and those stronger reactions then have a larger curative effect on liquidity.

Our second test exploits a placebo sample. Recall that our treatment and control samples screen out firms that have no history of providing guidance. We will now use non-guiders as a placebo to validate our empirical strategy indirectly. The logic of the placebo test is as follows. When a non-guider suffers a coverage shock, its liquidity should decrease, just as it does for a guider. There are three possible scenarios for what happens next. Under the overreaction hypothesis, investors subsequently correct their overreaction. Under our conjecture, non-guiders either respond to the coverage shock by becoming guiders or - if the marginal cost of initiating guidance exceeds the expected benefit - they do nothing.

The first two scenarios would result in subsequent reversals, so if we observe reversals among non-guiders, we cannot, in principle, discriminate between the overreaction hypothesis and our conjecture that reversals reflect management efforts to fill the information gap through increased voluntary disclosure. However, as we have already seen, non-guiders rarely become guiders after suffering a coverage shock. ${ }^{15}$ Thus, in practice, a finding of reversals among nonguiders would be most consistent with the overreaction hypothesis. Absence of subsequent reversals, on the other hand, would be inconsistent with overreaction while being consistent with our conjecture.

\footnotetext{
${ }^{15}$ See footnote 5 .
} 
To test this, we create a matched sample of non-guiders using the same algorithm as for the guiders. We start with the 1,122 shocks suffered by non-guiders (see Table 1), remove serially shocked firms, and find eligible controls matched on size, analyst coverage, volatility, and AIM. This yields 769 panels of treated firms and 769 panels of matched controls. Only 27 of the 769 treated non-guiders (3.5\%) become guiders in the quarter after their coverage shock.

Column 5 of Table 4 estimates the liquidity regression in the non-guider sample. As in the guider sample, we find a strong and significant contemporaneous effect of coverage shocks on the liquidity of non-guiders. The point estimate of 0.021 is three times larger than the equivalent point estimate of 0.007 for guiders in column 3 . This reflects the fact that non-guiders are smaller (mean: $\$ 4$ billion) and covered by fewer analysts (mean: 4.8) than are guiders, and so are more sensitive to shocks to their information environments. More importantly, for our purposes, we find that the contemporaneous increase in illiquidity following coverage shocks is not subsequently reversed. The effect of lagged shocks on AIM is an insignificant -0.006 ( $p=0.417)$.

This absence of reversals among treated non-guiders contrasts with the strong evidence of reversal among treated guiders. Like the results of our multiple-shock test, it is hard to reconcile with an overreaction story. Instead, it is consistent with our conjecture that guiders respond to coverage shocks by disclosing more information, which leads to a subsequent improvement in liquidity, while non-guiders choose not to become guiders and so their liquidity remains depressed. ${ }^{16}$

\subsection{Reversals and Price Changes}

Liquidity reversals raise an intriguing question. If liquidity recovers post-shock, why do share prices fall so much at the time of termination as shown in Kelly and Ljungqvist (2011)?

\footnotetext{
${ }^{16}$ Why wouldn't non-guiders start guiding when hit with a coverage shock? The literature suggests that it is a sustained commitment to disclosure that improves a firm's information environment, not a one-off piece of guidance (see Diamond and Verrecchia (1991) or Leuz and Verrecchia (2000)). Once begun, guidance is costly to discontinue: Chen and Zhang (2008) show that discontinuation announcements lead to significant share price falls and that analysts interpret them as implicit admissions that future earnings will be lower than expected. Firms are thus unlikely to start guiding opportunistically.
} 
There are two possible explanations. First, firms must now internalize the cost of information production associated with increased disclosure, whereas previously the brokerage house effectively subsidized the firm's information production costs by publishing analyst research. Investors understand this and so prices fall at the time of the shock. Second, Kelly and Ljungqvist's sample pools guiders and non-guiders. A comparison of our diff-in-diff to theirs shows that non-guiders suffer larger increases in illiquidity. They are also unlikely to respond to the coverage shock by becoming guiders. We thus expect them to suffer larger price falls, and the data support this: Non-guiders experience a price decline 33\% more severe than firms that are willing to guide. ${ }^{17}$

\subsection{Identifying Assumptions}

The results in Table 4 suggest that contemporaneous coverage shocks are not a suitable candidate for instrumenting voluntary disclosure, since they directly affect a firm's liquidity and so violate the exclusion restriction. But lagged coverage shocks have the potential to be a valid instrument. Their reduced-form effect on illiquidity in Table 4 is negative, which is consistent with the proposed disclosure channel. This is reassuring. As Angrist and Krueger (2001) note, if we do not see the proposed causal relation of interest in the reduced form, it is probably not there.

To be a valid instrument, lagged coverage shocks must satisfy two conditions. First, they must not correlate directly with liquidity other than through their effect on disclosure. While contemporaneous shocks should (and do) increase illiquidity, it is not obvious why lagged shocks would directly reduce illiquidity, at least once investor overreaction is ruled out. In fact, it is hard to think of an alternative channel, besides disclosure, that would cause the increase in illiquidity to subsequently reverse. Second, coverage shocks must correlate with voluntary

\footnotetext{
${ }^{17}$ On the termination day, the average abnormal return for non-guiders is $-1.34 \%$ compared to an average abnormal return of $-1.01 \%$ for guiders. The difference in these means is statistically significant with a $p$-value of 0.030 .
} 
disclosure, and to avoid weak-instrument problems, must do so 'strongly.'

We next test directly whether firms (specifically, guiders) indeed disclose more information when their information environment has been hit with an exogenous shock.

\section{Guidance Response to Exogenous Shocks to Information Environment}

\subsection{Baseline Models}

Table 5, Panel A relates one particular form of voluntary disclosure - management forecasts of quarterly earnings - to coverage shocks dated from $t=-4$ to $t=+4$. Following Angrist (2001), column 1 is estimated as a linear probability model with firm fixed effects. An exogenous coverage shock has a positive and significant contemporaneous effect on the probability that a firm issues a forecast at $t=0$ ( $p<0.001$ when standard errors are clustered by firm). The economic magnitude is sizeable: Firms suffering coverage shocks are 4.9 percentage points more likely to issue a forecast than are observably similar control firms. Relative to the pre-shock probability of $27.5 \%$ reported in Table 2 , this represents an increase of $17.8 \%(0.049 / 0.275-1)$. This result is consistent with our conjecture that guiders respond to coverage shocks by disclosing more information and supports the validity of the proposed instrument.

The first three lags of the shock indicator are also positive and statistically significant (at the 0.013 level or better), suggesting that firms increase their voluntary disclosure for a period of one year following a coverage shock. The lagged coefficients are somewhat smaller than the contemporaneous effect but remain sizeable (0.033 to 0.042 ). We find no evidence that firms anticipate future shocks, in view of the small and insignificant coefficients estimated for the leads. This supports Kelly and Ljungqvist's (2011) conclusion that the coverage shocks are exogenous. Among the firm characteristics, only size is significant; it has a positive effect on disclosure. Overall, the regression has good fit in light of the relatively high $R^{2}$ of $49.7 \%$.

Column 2 shows what happens if instead of clustering the standard errors by firm, we cluster by calendar quarter. As in the diff-in-diffs shown in Table 3, where we also cluster by quarter, 
this helps to adjust for potential cross-sectional dependence due to time clustering of the 43 brokerage closures. The results are virtually identical: The $p$-value for contemporaneous shocks increases marginally from $<0.001$ to 0.004 while those for the first three lags range from 0.019 to 0.028 .

Linear probability models are simple to estimate but sometimes generate coefficients that imply probabilities outside the unit interval. While the results in columns 1 and 2 suggest that this potential drawback does not apply in our case, it is worthwhile to check if our results are robust to estimating a logit model with firm fixed effects instead. This is shown in column 3 . None of our conclusions is affected, so in the remainder of the paper, we report linear probability models whenever the dependent variable is binary.

As a further robustness check, column 4 models the number of forecasts management issues in a quarter, instead of the probability of a forecast being issued. Given the count nature of this dependent variable, we estimate a Poisson model with firm fixed effects. This too leaves our conclusions unaffected: Firms respond to coverage shocks by increasing their disclosure, and they sustain increased disclosure for a period of four quarters.

\subsection{What Kind of Information Do Firms Disclose?}

As we saw in Table 2, voluntary guidance can take a number of forms. Panel B of Table 5 relates the eight guidance measures introduced in Table 2 to coverage shocks and firm characteristics. Given the results of Panel A, we focus on shocks dated $t=-3$ to $t=0$ and estimate linear probability models with firm, year, and fiscal-quarter fixed effects. Standard errors are clustered by firm as before. The first three columns focus on the guidance horizon and show that firms respond to coverage shocks by issuing forecasts of future quarterly earnings rather than pre-announcing imminent earnings. They are thus more likely to issue guidance earlier in the fiscal quarter, consistent with the view that pre-announcements are largely nondiscretionary, reflecting for example profit warnings. 
The next two columns distinguish between quantitative and qualitative guidance. With the exception of a small and marginally significant coefficient for shocks at $t=-2$, we find no evidence that firms become more likely to issue qualitative guidance following coverage shocks. They do, however, become significantly more likely to issue quantitative guidance, and the effect is again economically large and sustained for a period of four quarters.

The final three columns consider the content of the guidance. In response to losing coverage, firms become $15.8 \%$ more likely to disclose negative news $(p=0.002),{ }^{18}$ but they do not increase their disclosure of positive news, nor do they become more likely to release information that amounts to 'hot air'. (As an aside, the coefficients for the indicator capturing firms that are net equity issuers tell an interesting story. All else equal, such firms are significantly less likely to reveal negative news and significantly more likely to disclose positive news and to issue 'hot air' guidance.)

\subsection{Do Firms Disclose More When Hit With More Severe Shocks?}

Our final examination of firms' guidance responses to coverage shocks focuses on different types of shock. In column 1 of Table 5, Panel C, we let the response depend on how many coverage shocks a firm suffers in a quarter. As in column 4 of Table 4, we do so by adding two indicator variables set equal to 1 if a firm suffered multiple coverage shocks in quarters $t=0$ or $t$ $=-1$. Both coefficients are positive and statistically significant (at the $0.2 \%$ and the $3.5 \%$ levels, respectively), and they are large: Relative to firms that suffer a single coverage shock in quarter $t$ $=0$, firms hit with multiple shocks are an additional 13.6 percentage points more likely to issue a management forecast, for a total increase in that likelihood of 16.5 percentage points $(=0.136+$ 0.029). One quarter later, the likelihood is 9.1 percentage points greater following multiple shocks than following single shocks. For comparison, the pre-shock likelihood of a firm issuing a

\footnotetext{
${ }^{18}$ This compares the coefficient of 0.029 in column 6 to the pre-shock likelihood of a treated firm releasing negative news (0.183 in Table 2$)$.
} 
forecast is $27.5 \%$ (see Table 2), so firms' responses to multiple shocks are quite sizeable.

Kelly and Ljungqvist (2011) show that exogenous terminations involving 'local' analysts (those that are located close to a firm's headquarters) are associated with significantly larger price falls. This is consistent with prior evidence (e.g., Malloy (2005)) that local analysts provide more accurate earnings forecasts and thus more pricing-relevant signals. In columns 2 through 4 , we investigate whether firms respond more strongly to the loss of a local analyst than to that of a more distant analyst. Column 2 codes a local analyst as one located within a 50-mile radius of the firm's headquarters. ${ }^{19}$ Upon losing a distant analyst, firms are 2.7 percentage points more likely to issue a forecast than are their controls $(p=0.002)$. Upon losing a local analyst, this likelihood increases by an additional 5.5 percentage points $(p=0.003)$ for a total increase of 8.2 percentage points $(=0.027+0.055)$ relative to the controls $(p<0.001)$. Columns 3 and 4 expand the radius to 100 miles and 200 miles, respectively, which reduces the differential effect somewhat, from 5.5 to 5.0 and 3.2 percentage points (both significant at the $5 \%$ level or better). These results indicate that firms step up their disclosure especially after losing a more local analyst.

Kelly and Ljungqvist (2011) predict that closures of institutions-only brokers should have a smaller (or no) effect on share prices than closures of retail brokers and find this to be true. For our purposes, this should translate into a smaller (or no) guidance response following loss of an institutional analyst than a retail analyst, since many institutions can either obtain the lost analyst signal from another broker or substitute for it in-house. Column 5 adds an indicator set equal to 1 if a firm loses an institutional analyst to capture the incremental effect relative to losing a retail analyst. The results confirm our prediction. Upon losing a retail analyst, firms are 5.6 percentage points more likely to issue guidance $(p<0.001)$. In contrast, firms do not respond to loss of an

\footnotetext{
${ }^{19}$ Analyst locations as of the brokerage closure date come from Nelson's Directory of Investment Research or, where unavailable, the analyst's telephone number as per his or her research reports in the Investext archive. Headquarter locations come from the firm's most recent $10-\mathrm{Q}$ and $10-\mathrm{K}$ filing before the termination date (not from Compustat, as Compustat's location information reflects a firm's location as of the download date).
} 
institutional analyst: The incremental effect is -4.8 percentage points, meaning they are only 0.8 percentage points more likely than their controls to issue guidance that quarter $(=0.056-0.048)$. This is neither large economically nor significant statistically $(p=0.454)$. These patterns suggest the possibility that firms target retail investors with their voluntary disclosures.

Columns 6 through 8 examine firms' reactions to coverage shocks that had a particularly severe effect on their liquidity, measured using the diff-in-diff change in Amihud's (2002) illiquidity measure, $\triangle A I M$. In column 6 , we code firms with above-median $\triangle A I M$ as suffering a severe shock to their liquidity. Firms suffering non-severe (below-median) shocks are nearly as likely as their controls to issue a management forecast: The coefficient estimate for contemporaneous shocks is 0.008 with a $p$-value of 0.426 . Firms coded as suffering severe shocks, on the other hand, are 5.1 percentage points more likely to issue a forecast than firms suffering below-median shocks and 5.9 percentage points more likely to do so than their controls $(=0.051+0.008)$. Both differences are highly statistically significant $(p<0.001)$.

Column 7 repeats this exercise with a higher threshold, namely firms with $\triangle A I M$ in the top quartile of the distribution. The results are similar to those in column 6 , except that the effect of non-severe shocks (those in the first three quartiles) becomes larger and statistically significant (presumably due to the experience of third-quartile firms, which are coded as suffering severe shocks in column 6 but not in column 7). In column 8 , we code severe shocks as those leading to a $\triangle A I M$ that is significantly different from zero at the $5 \%$ level (in a two-tailed test). The estimates resemble those in the other specifications. Thus, irrespective of the way we measure severity, our results suggest that firms respond more strongly to more severe shocks to their liquidity.

\subsection{Summary}

The results in Table 5 confirm our conjecture that firms respond to shocks to their 
information environments by providing voluntary disclosure. From an identification point, this is encouraging: Essentially, the specifications in Table 5 represent the first stage in a two-stage least squares model that instruments disclosure with coverage shocks, and we have found a strong correlation between coverage shocks and disclosure in the first stage, as required for identification.

Before we can estimate the second stage, we need to verify that the data support the timeline that our identification strategy assumes. Table 5 implies that contemporaneous shocks affect disclosure, while Table 4 implies that contemporaneous shocks violate the exclusion restriction. Thus, we have no instrument for the contemporaneous effect of disclosure on liquidity. But we can potentially exploit lagged coverage shocks as an instrument for similarly lagged disclosure choices, as lagged coverage shocks have no apparent direct effect on liquidity. This approach raises two questions, which we address next: Does disclosure correlate with liquidity contemporaneously (which would be problematic since we cannot instrument it)? And does lagged disclosure affect liquidity (which would be desirable since we are able to instrument lagged disclosure)?

\section{The Effect of Voluntary Disclosure on Liquidity}

\section{1 'Nä̈ve' Relation Between Voluntary Disclosure and Liquidity}

To shed light on these questions, we estimate 'naïve' regressions of AIM on voluntary guidance. They are naïve in the sense that they do not attempt to correct for the endogeneity of guidance. Column 1 of Table 6 includes indicator variables for contemporaneous and oncelagged management forecasts alongside firm characteristics and firm, year, and fiscal-quarter fixed effects. The coefficient estimate for contemporaneous guidance is negative but small, at 0.0035 , and not statistically different from zero $(p=0.227)$. The estimate for lagged guidance of $0.010(p=0.006)$ is nearly three times larger. This supports the timeline underpinning our identification strategy. 
The remaining eight columns of Table 6 regress AIM on the first lag of the eight guidance measures introduced in Table 2. We find significant correlations between liquidity and each of lagged managed forecasts, quantitative and qualitative guidance, and negative news, but not between liquidity and pre-announcements, positive news, or guidance that amounts to hot air.

Table 6 also reports tests for first-order serial correlation in the dependent variable using the modified Durbin-Watson test developed for panel-data models by Bhargava, Franzini, and Narendranathan (1982). The test fails to reject the null of no first-order serial correlation in Amihud's (2002) illiquidity measure and thus supports our chosen regression specification. ${ }^{20}$

\subsection{Causal Effect of Voluntary Disclosure on Liquidity}

We can now estimate the causal effect of voluntary disclosure at $t=0$ on liquidity at $t=+1$ using exogenous coverage terminations dated $t=-3$ to $t=0$ as instruments. (See Table 5, Panel $\mathrm{B}$ for the corresponding first-stage estimates.) To recap, the key identifying assumption is that coverage shocks dated -3 to 0 do not affect liquidity in quarter $t=+1$ other than through their effect on the firm's guidance choice. (See Table 4 for the corresponding reduced-form estimates.)

Since identification requires that the instrument must correlate strongly with the endogenous variable, we focus on the four disclosure choices that, according to the first-stage estimates in Table 5, Panel B, respond significantly to the instrument: Management forecasts, forecasts or pre-announcements, quantitative guidance, and negative news. We compute Staiger-Stock (1997) tests of weak instruments and find that coverage shocks are strong instruments for each of these four disclosure choices.

Table 7 reports the results. Across the four specifications, we find that voluntary disclosure has a large and negative causal effect on a firm's subsequent illiquidity: That is, disclosure improves liquidity. The sign of this relation is the same as in the naïve regressions in Table 6 , but

\footnotetext{
${ }^{20}$ Accordingly, our findings are robust to allowing for an AR(1) process in the dependent variable.
} 
the magnitude of the effect is between 7 and 12 times greater: The coefficient estimates vary from -0.075 for management forecasts to -0.148 for negative news. (Each coefficient is statistically significant, with $p$-values ranging from 0.034 for management forecasts to 0.001 for negative news.) The large difference between the naïve and the structural coefficients suggests that failure to control for the endogeneity of voluntary disclosure seriously biases estimates of the beneficial effect of disclosure on liquidity.

\subsection{Robustness Tests}

Our tests so far have used Amihud's (2002) illiquidity measure to proxy for liquidity. Bidask spreads are another popular proxy, and Kelly and Ljungqvist (2011) show that spreads increase significantly following exogenous coverage terminations. We now test whether our results are robust to modeling the causal effect of voluntary disclosure on bid-ask spreads instead of on AIM. As before, we focus on the four guidance choices that respond to coverage shocks: Forecasts, forecasts and pre-announcements, quantitative guidance, and negative news.

The estimates, reported in Table 8, show that our conclusions hold whether we model AIM or bid-ask spreads. We find that spreads decline significantly in response to each of the four guidance choices, as instrumented using exogenous coverage shocks. If anything, the results are statistically somewhat stronger than in Table 7.

\section{Conclusions}

Our tests exploit a natural experiment, first explored in Kelly and Ljungqvist (2011), that amounts to a plausibly exogenous shock to a stock's information environment. This allows us not only to investigate how firms respond to such shocks but also to establish how firms' responses in turn affect liquidity. The exogenous nature of the shocks allows us to instrument firms' responses and thus to establish a causal link between voluntary disclosure and liquidity.

We have three main results. First, we show that firms respond to shocks to their information environments by stepping up disclosure. A closer look at the types of disclosure they provide is 
instructive. Firms favor making management earnings forecasts over pre-announcing earnings; they provide more quantitative than qualitative information; and they are more likely to release negative news but not positive news or uninformative guidance.

Second, firms respond only to the loss of coverage by a retail analyst and not when they lose coverage by an analyst serving institutional investors. This novel stylized fact is consistent with the notion that voluntary disclosure is motivated by a desire to communicate with retail investors. Since retail investors are often thought of as being at an informational disadvantage relative to institutions, firms appear to view disclosure as a way to reduce information asymmetries among investors. Theoretical asset pricing models show that reducing information asymmetries leads to higher share prices and a lower cost of capital.

Third, we show that voluntary disclosure has a large and beneficial effect on liquidity and that this effect is plausibly causal. This result provides a justification to firms for voluntarily disclosing more information than is mandated by law and regulations, despite the potential for shareholder lawsuits claiming 'inaccurate' or 'misleading' disclosure or the possibility that product-market competitors might gain a commercial advantage. 


\section{References}

Admati, Anat R., and Paul Pfleiderer, 2000, Forcing firms to talk: Financial disclosure regulation and externalities, Review of Financial Studies 13, 479-519.

Amihud, Yakov, and Haim Mendelson, 1986, Asset pricing and the bid-ask spread, Journal of Financial Economics 17, 223-249.

Amihud, Yakov, and Haim Mendelson, 1989, The effects of beta, bid-ask spread, residual risk, and size on stock returns, Journal of Finance 44, 479-486.

Amihud, Yakov, 2002, Illiquidity and stock returns: Cross-section and time series effects, Journal of Financial Markets 5, 31-56.

Anantharaman, Divya, and Yuan Zhang, 2011, Cover me: Managers' response to changes in analyst coverage in the post-Regulation FD period, Accounting Review, forthcoming.

Angrist, Joshua, 2001, Estimation of limited endogenous variable models with dummy endogenous regressors: Simple strategies for empirical practice, Journal of Business and Economic Statistics 19, 2-16.

Angrist, Joshua, and Alan B. Krueger, 2001, Instrumental variables and the search for identification: From supply and demand to natural experiments, Journal of Economic Perspectives 15, 69-85.

Anilowski, Carol, Mei Feng, and Douglas J. Skinner, 2007, Does earnings guidance affect market returns? The nature and information content of aggregate earnings guidance, Journal of Accounting and Economics 44, 36-63.

Bertrand, Marianne, Esther Duflo, and Sendhil Mullainathan, 2004, How much should we trust difference in difference estimates?, Quarterly Journal of Economics 119, 249-275.

Bhargava, Alok, Louisa Franzini, and Wiji Narendranathan, 1982, Serial correlation and the fixed effects model, Review of Economic Studies 49, 533-549.

Bhattacharya, Sudipto, and Jay R. Ritter, 1983, Innovation and communication: Signalling with partial disclosure, Review of Economic Studies 50, 331-346.

Boot, Arnoud W.A., and Anjan V. Thakor, 2001, The many faces of information disclosure, Review of Financial Studies 14, 1021-1057.

Botosan, Christine, 1997, Disclosure level and the cost of equity capital, Accounting Review 72, 323-349.

Botosan, Christine, and Marlene Plumlee, 2002, A re-examination of disclosure level and the expected cost of equity capital, Journal of Accounting Research 40, 21-40.

Breen, William J., Laurie S. Hodrick, and Robert A. Korajczyk, 2002, Predicting equity liquidity, Management Science 48, 470-483.

Brennan, Michael J., and Avanidhar Subrahmanyam, 1996, Market microstructure and asset pricing: On the compensation for illiquidity in stock returns, Journal of Financial Economics 41, 441-464.

Brown, Stephen, and Stephen Hillegeist, 2007, How disclosure quality affects the level of information asymmetry, Review of Accounting Studies 12, 443-477. 
Campbell, Tim S., 1979, Optimal investment financing decisions and the value of confidentiality, Journal of Financial and Quantitative Analysis 14, 913-924.

Chen, Peter F., and Guochang Zhang, 2007, How do accounting variables explain stock price movements? Theory and evidence, Journal of Accounting and Economics 43, 219-244.

Chen, Shuping, Dawn A. Matsumoto, and Shivaram Rajgopal, 2011, Is silence golden? An empirical analysis of firms that stop earnings guidance, Journal of Accounting and Economics 51, 134-150.

Chordia, Tarun, Richard Roll, and Avanidhar Subrahmanyam, 2000, Commonality in liquidity, Journal of Financial Economics 56, 3-28.

Coller, Maribeth, and Teri Yohn, 1997, Management forecasts and information asymmetry: An examination of bid-ask spreads, Journal of Accounting Research 35, 181-191.

Diamond, Douglas W., 1985, Optimal release of information by firms, Journal of Finance 40, 1071-1094.

Diamond, Douglas W., and Robert E. Verrecchia, 1991, Disclosure, liquidity, and the cost of capital, Journal of Finance 46, 1325-1359.

Easley, David, and Maureen O'Hara, 2004, Information and the cost of capital, Journal of Finance 59, 1553-1583.

Fama, Eugene F., and Arthur B. Laffer, 1971, Information and capital markets, Journal of Business 44, 289-298.

Fishman, Michael J., and Kathleen M. Hagerty, 1989, Disclosure decisions by firms and the competition for price efficiency, Journal of Finance 44, 633-646.

Francis, Jennifer, Donna Philbrick, and Katherine Schipper, 1994, Shareholder litigation and corporate disclosures, Journal of Accounting Research 32, 137-164.

Frank, Murray Z., and Vidhan K. Goyal, 2003, Testing the pecking order theory of capital structure, Journal of Financial Economics 67, 217-248.

$\mathrm{Fu}$, Renhui, Arthur Kraft, and Huai Zhang, 2011, Financial reporting frequency, information asymmetry, and the cost of equity, Unpublished working paper, Wharton.

Graham, John R., Campbell R. Harvey, and Shivaram Rajgopal, 2005, The economic implications of corporate financial reporting, Journal of Accounting and Economics 40, 3-73.

Hakansson, Nils H., 1977, Interim disclosure and public forecasts: An economic analysis and a framework for choice, Accounting Review 52, 396-426.

Hakansson, Nils H., J. Gregory Kunkel, and James A. Ohlson, 1982, Sufficient and necessary conditions for information to have social value in pure exchange, Journal of Finance 37, 1169-1181.

Hirshleifer, Jack, 1971, The private and social value of information and the reward to inventive activity, American Economic Review 61, 561-574.

Houston, Joel F., Baruch Lev, and Jennifer W. Tucker, 2007, To guide or not to guide? Causes and consequences of stopping quarterly earnings guidance, Unpublished working paper, University of Florida. 
Hsieh, Peggy, Timothy Koller, and S.R. Rajan, 2006, The misguided practice of earnings guidance, McKinsey on Finance.

Irvine, Paul J., 2003, The incremental impact of analyst initiation of coverage, Journal of Corporate Finance 9, 431-451.

Kelly, Bryan, and Alexander Ljungqvist, 2011, Testing asymmetric-information asset pricing models, Review of Financial Studies, forthcoming.

Kim, Oliver, 1993, Disagreements among shareholders over a firm's disclosure policy, Journal of Finance 48, 747-760.

Lang, Mark and Russell Lundholm, 1993, Cross-sectional determinants of analyst ratings of corporate disclosures, Journal of Accounting Research 31, 246-271.

Lang, Mark and Russell Lundholm, 1996, Corporate disclosure policy and analyst behavior, Accounting Review 71, 467-493.

Leuz, Christian, and Catherine Schrand, 2009, Disclosure and the cost of capital: Evidence from firms' responses to the Enron shock, Unpublished working paper, University of Chicago.

Leuz, Christian, and Robert E. Verrecchia, 2000, The economic consequences of increased disclosure, Journal of Accounting Research 38, 91-124.

Leuz, Christian, and Peter D. Wysocki, 2008, Economic consequences of financial reporting and disclosure regulation: A review and suggestions for future research, Unpublished working paper, University of Chicago.

Li, Yuan, 2011, Information asymmetry and management earnings forecast: Evidence from brokerage houses merger, Unpublished working paper, Deakin University.

Malloy, Christopher, 2005, The geography of equity analysis, Journal of Finance 60, 719-755.

Skinner, Douglas J., 1994, Why firms voluntarily disclose bad news, Journal of Accounting Research 32, 38-60.

Staiger, Douglas, and James H. Stock, 1997, Instrumental variables regression with weak instruments, Econometrica 65, 557-586.

Trueman, Brett, 1983, Optimality of the disclosure of private information in a productionexchange economy, Journal of Finance 38, 913-924.

Verrecchia, Robert E., 1999, Disclosure and the cost of capital: A discussion, Journal of Accounting and Economics 26, 271-283. 


\section{Appendix A. Variable Definitions.}

Market capitalization is defined as the fiscal quarter-end share price (CRSP variable prc) times the number of shares outstanding (CRSP variable shrout).

\# analysts providing coverage is the maximum number of different analysts providing a forecast of earnings per share in the 90 days prior to the earnings announcement date ( $\mathrm{I} / \mathrm{B} / \mathrm{E} / \mathrm{S}$ variable anndats) in a given fiscal quarter, taken from the unadjusted detail files maintained by $\mathrm{I} / \mathrm{B} / \mathrm{E} / \mathrm{S}$.

Volatility is the standard deviation of daily returns (obtained from CRSP).

$\log$ AIM is the quarterly average of the natural log of 1 plus Amihud's (2002) illiquidity measure (AIM). It is constructed as follows. Following Amihud, we use daily CRSP data (CRSP variables ret, prc, and vol) to calculate the ratio of absolute stock return to dollar volume $[1,000,000 *|r e t| \div(|\operatorname{prc}| * v o l)]$ for each day in a fiscal quarter. We then average these daily AIM over the fiscal quarter and take logs.

Bid-ask spread is the quarterly average of the firm's daily bid-ask spread (BAS). It is constructed as follows. We use daily closing bid and ask data from CRSP (CRSP variables ask and bid) to calculate $100 *$ (ask-bid)/[(ask+bid)/2]. We then average these daily bid-ask spreads over the fiscal quarter. Observations with crossed quotes (negative spreads) are excluded.

Net equity issuance is an indicator variable set equal to 1 if the firm's net equity issues in the fiscal year are positive. Following Frank and Goyal (2003), we calculate net equity issues as sales of common and preferred stock (Compustat item sstk) minus purchases of common and preferred stock (Compustat item prstkc).

Forecast/pre-announcement is an indicator variable set equal to 1 if the firm provides earnings guidance (in the form of a forecast or a pre-announcement) in the fiscal quarter. We obtain guidance data from the Company Issued Guidelines (CIG) files of the First Call Historical Database (FCHD) maintained by Thomson Reuters. We limit analysis to quarterly forecasts and pre-announcements of earnings per share (periodicity = ' $\mathrm{Q}$ ' and data_type= 'EPS') for the firm's common stock (security_type = 'COM'). Following Anilowski, Feng, and Skinner (2007), we remove observations with missing earnings announcement dates (actdate) and those with guidance dates (anndate) occurring on or after the actual earnings announcement date.

Forecast is an indicator variable set equal to 1 if management supplies earnings guidance prior to the end of the fiscal period (anndate $<$ fpe).

Pre-announcement is an indicator variable set equal to 1 if management supplies earnings guidance after the end of the fiscal period but before the formal announcement of earnings (fpe $<$ anndate).

Quantitative guidance is an indicator variable set equal to 1 if the earnings guidance contains a numerical estimate.

Qualitative guidance is an indicator variable set equal to 1 if the earnings guidance contains no numerical estimate.

For quantitative guidance, following Anilowski, Feng, and Skinner (2007), we code three additional variables relating to its content. To do so, we obtain analyst forecast data from the Summary Statistics files of the FCHD. This dataset supplies the prevailing consensus estimate on any given day. To ensure that the guidance does not influence our measure of the prevailing consensus, we measure consensus as the median analyst forecast of earnings per share as of the day before the guidance date (anndate -1$)$.

Negative news is an indicator variable set equal to 1 if management supplies an earnings estimate that falls below the prevailing consensus (i.e., the median analyst forecast) as of the day before the guidance date (anndate - 1).

Positive news is an indicator variable set equal to 1 if management supplies an earnings estimate that exceeds the prevailing consensus (i.e., the median analyst forecast) as of the day before the guidance date (anndate - 1).

Hot air is an indicator variable set equal to 1 if management supplies an earnings estimate that equals the prevailing consensus (i.e., the median analyst forecast) as of the day before the guidance date (anndate - 1). 
Distance is the geographic distance between the locations of each analyst-company pair using the Haversine formula. Locations are coded by Zip code that are translated into longitudes and latitudes using the Census 2000 U.S. Gazeteer (http://www.census.gov/tiger/tms/gazetteer/zcta5.txt). 
Figure 1. Average Daily Amihud Illiquidity Measure, All CRSP Firms, 1999-2010.

The figure shows the value-weighted average daily log Amihud illiquidity measure for the universe of firms in CRSP for the period from 1999 to 2010.

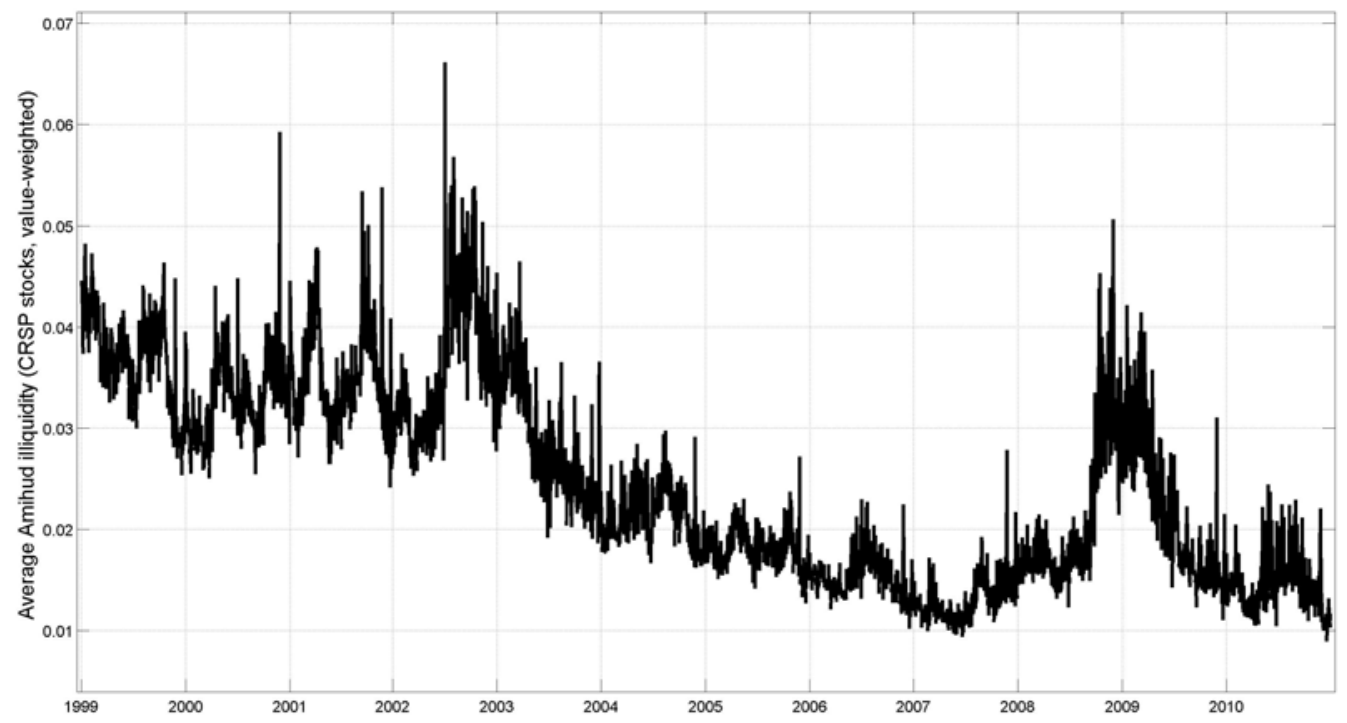


Figure 2. Overview of First Call's Guidance Data.

The top left graph shows the quarterly number of pieces of quarterly guidance issued voluntarily by management according to the 'Company Issued Guidelines' files of the First Call Historical Database. The other three graphs break down the guidance by horizon (top right), form (bottom left), and content (bottom right).
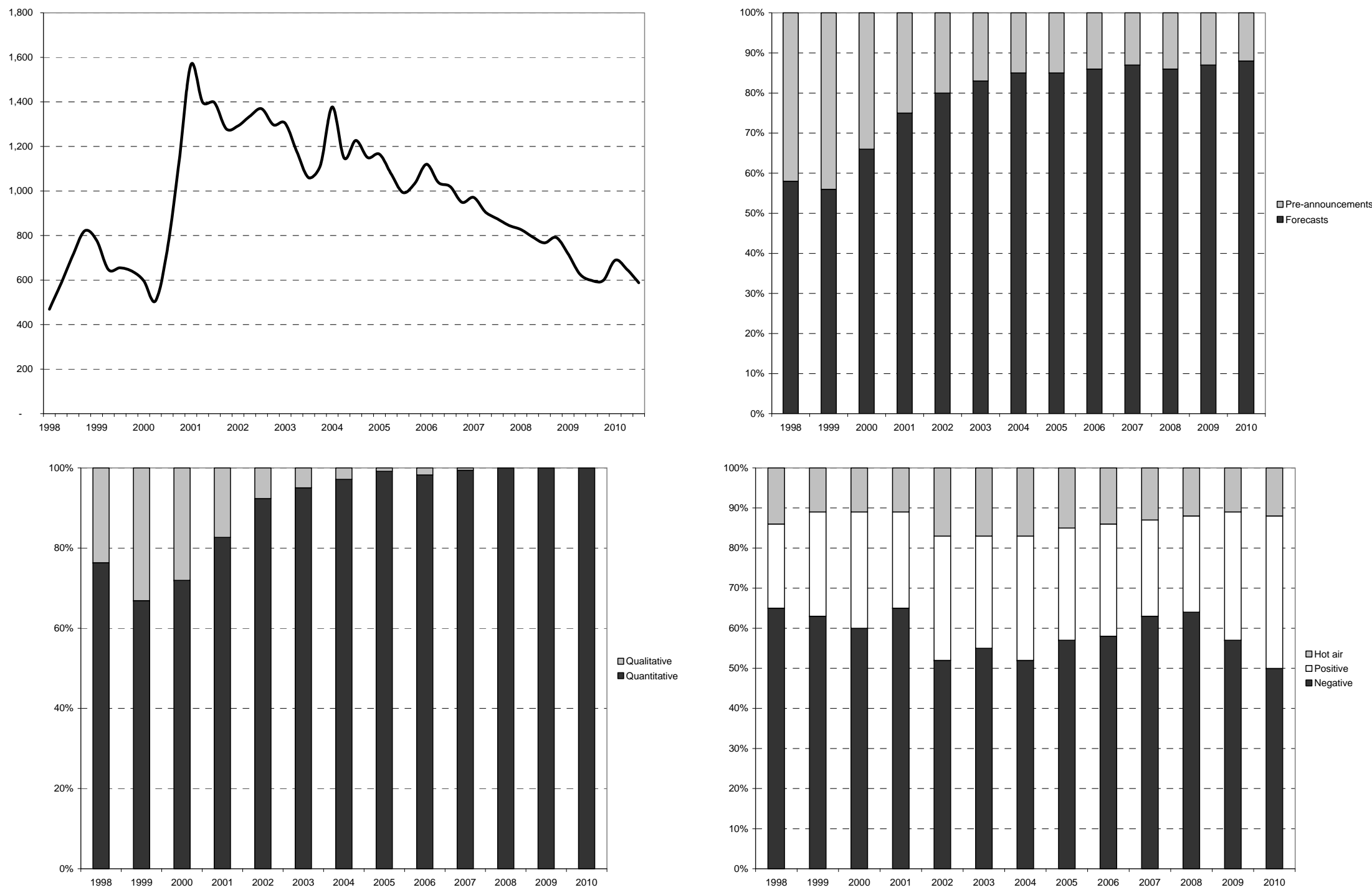


\section{Table 1. Construction of Treatment Sample.}

Kelly and Ljungqvist (2011) identify a sample of 4,429 exogenous coverage terminations affecting 2,180 unique firms as a result of 43 brokerage closures over the period Q2, 2000 through Q1, 2008. Their unit of analysis is a firm-day. We focus instead on firm-fiscal quarters. Some firms are hit with multiple exogenous coverage terminations in a given fiscal quarter, leaving 4,185 firm-fiscal quarters with one or more termination events. We filter out 1,922 firm-fiscal quarters as set out below, and lose 168 firm-fiscal quarters for which no valid match can be found in a nearest-neighbor propensity score match using a 0.005 caliper. This yields a final treatment sample consisting of 2,095 firm-fiscal quarters with one or more exogenous coverage termination events for 1,468 unique firms.

\begin{tabular}{|c|c|c|c|c|c|}
\hline & & \multirow[t]{2}{*}{ Total } & \multicolumn{3}{|c|}{$\begin{array}{l}\text { Number of terminations } \\
\text { per firm-fiscal quarter }\end{array}$} \\
\hline & & & 1 & 2 & 3 \\
\hline \multicolumn{6}{|l|}{ Kelly and Ljungqvist (2011): } \\
\hline \# unique treated firms (by Compustat gvkey) & & 2,180 & & & \\
\hline \# coverage termination events & & 4,429 & 3,948 & 460 & 21 \\
\hline \# firm-fiscal quarters $\mathrm{w} /$ one or more termination events & & 4,185 & & & \\
\hline less: not yet guiders as of termination quarter & $-1,122$ & & & & \\
\hline less: serially shocked firms & -794 & & & & \\
\hline less: not traded in fiscal quarter before termination & -4 & & & & \\
\hline less: lose coverage in firm's last fiscal quarter of listing & -2 & & & & \\
\hline Treated firm-fiscal quarters eligible for matching & & 2,263 & & & \\
\hline less: no valid match with 0.005 caliper & -168 & & & & \\
\hline \multicolumn{6}{|l|}{ Final treatment sample: } \\
\hline \# firm-fiscal quarters w/ one or more termination events & & 2,095 & & & \\
\hline \# coverage termination events & & 2,821 & 2,561 & 236 & 24 \\
\hline \# unique treated firms (by Compustat gvkey) & & 1,468 & & & \\
\hline
\end{tabular}




\section{Table 2. Descriptive Statistics.}

The sample consists of 2,095 stocks that suffer an exogenous coverage termination ('treated firms') and 2,095 'control firms.' Treated and control firms are matched on market capitalization, volatility, the number of analysts providing coverage, and the Amihud illiquidity measure (AIM), all measured as of the fiscal quarter before the coverage termination. The match is performed using a nearest-neighbor propensity score match with a 0.005 caliper. The table reports the firm characteristics we match on and the resulting propensity scores (Panel A) as well as a variety of voluntary management guidance measures (Panel B). All variables are measured as of the time of the match, i.e., the fiscal quarter before the coverage termination. We tabulate means, medians, and standard deviations for continuous variables and fractions for indicator variables. We also report pairwise differences in means, fractions, and medians between treated and contro firms. To estimate statistical significance, we use $t$-tests (for means and fractions) and Pearson $\chi^{2}$ tests (for medians). None of the differences between treated and control firms is significant at the $10 \%$ level or better. For variable definitions and details of their construction, see Appendix A.

\begin{tabular}{|c|c|c|c|c|c|c|c|c|}
\hline & \multicolumn{3}{|c|}{ Treated firms } & \multicolumn{3}{|c|}{ Control firms } & \multicolumn{2}{|c|}{ Treated - controls } \\
\hline & $\begin{array}{l}\text { Mean or } \\
\text { fraction }\end{array}$ & Std. dev. & Median & $\begin{array}{l}\text { Mean or } \\
\text { fraction }\end{array}$ & Std. dev. & Median & $\begin{array}{c}\text { Difference } \\
\text { in means/ } \\
\text { fractions }\end{array}$ & $\begin{array}{c}\text { Difference } \\
\text { in } \\
\text { medians } \\
\end{array}$ \\
\hline \multicolumn{9}{|l|}{ Panel A: Firm characteristics } \\
\hline \multicolumn{9}{|l|}{ Matching variables: } \\
\hline Market capitalization (\$m) & $7,860.8$ & $22,100.0$ & $1,486.9$ & 7,919.1 & $22,700.0$ & $1,564.1$ & -58.3 & -77.2 \\
\hline$\#$ analysts providing coverage & 6.9 & 5.8 & 5.0 & 7.0 & 5.9 & 6.0 & -0.1 & -1.0 \\
\hline Volatility & 0.032 & 0.022 & 0.026 & 0.033 & 0.029 & 0.026 & -0.001 & 0 \\
\hline $\log A I M$ & 0.049 & 0.256 & 0.002 & 0.049 & 0.299 & 0.002 & 0 & 0 \\
\hline Propensity score & 0.164 & 0.156 & 0.110 & 0.164 & 0.157 & 0.110 & 0 & 0 \\
\hline \multicolumn{9}{|l|}{ Panel B: Management guidance } \\
\hline \multicolumn{9}{|l|}{ Guidance horizon: } \\
\hline Forecast or pre-announcement & 0.334 & & & 0.319 & & & 0.015 & \\
\hline Forecast & 0.275 & & & 0.267 & & & 0.008 & \\
\hline Pre-announcement & 0.094 & & & 0.083 & & & 0.011 & \\
\hline \multicolumn{9}{|l|}{ Form of guidance: } \\
\hline Quantitative guidance & 0.304 & & & 0.299 & & & 0.004 & \\
\hline Qualitative guidance & 0.048 & & & 0.038 & & & 0.010 & \\
\hline \multicolumn{9}{|l|}{ Content of guidance: } \\
\hline Negative news & 0.183 & & & 0.176 & & & 0.008 & \\
\hline Positive news & 0.092 & & & 0.096 & & & -0.004 & \\
\hline 'Hot air' & 0.069 & & & 0.068 & & & 0.001 & \\
\hline
\end{tabular}




\section{Table 3. The Effect of Coverage Shocks on Liquidity: Diff-in-Diff Test.}

The table measures the impact of an exogenous coverage termination on a stock's liquidity using a difference-indifferences test. The exogenous coverage terminations occurred as a result of 43 brokerage closures over the period Q2, 2000 through Q1, 2008. The sample consists of 2,095 treated firms and 2,095 control firms. Treated and control firms are matched on market capitalization, volatility, the number of analysts providing coverage, and AIM, all measured as of the fiscal quarter before the coverage termination. Liquidity is measured using the log Amihud illiquidity measure (AIM). We report average levels of $\log A I M$ in the fiscal quarter before a coverage termination (labeled 'before') and in the following quarter (labeled 'after'). We also report within-firm changes (labeled 'difference') and between-firm differences (labeled 'treated - controls'). The change in the between-firm differences is the difference-in-differences. Standard errors, reported in italics underneath the averages, are obtained from a bootstrap stratified by quarter with 1,000 replications. The bootstrap adjusts for potential cross-sectional dependence due to overlapping estimation windows caused by time clustering as multiple stocks are terminated in each of the 43 brokerage-firm closures. We use $* * *$ and $* *$ to denote significance at the $1 \%$ and $5 \%$ level (two-sided), respectively. In the last row, we report within-firm differences in \% of the pre-shock level of log AIM as a measure of the economic significance of coverage shocks. Note that this statistic is estimated per firm and then averaged across firms; it is not the relative change in the reported averages.

\begin{tabular}{|c|c|c|c|}
\hline & $\begin{array}{c}\text { Treated } \\
\text { firms }\end{array}$ & $\begin{array}{c}\text { Control } \\
\text { firms }\end{array}$ & $\begin{array}{l}\text { Treated- } \\
\text { Controls }\end{array}$ \\
\hline Before & $\begin{array}{l}0.049 \\
0.006\end{array}$ & $\begin{array}{l}0.049 \\
0.006\end{array}$ & $\begin{array}{l}0.000 \\
0.008\end{array}$ \\
\hline After & $\begin{array}{l}0.073 \\
0.007\end{array}$ & $\begin{array}{l}0.063 \\
0.007\end{array}$ & $\begin{array}{l}0.010 \\
0.010\end{array}$ \\
\hline Difference & $\begin{array}{l}0.024^{* * *} \\
0.003\end{array}$ & $\begin{array}{l}0.014^{* * *} \\
0.003\end{array}$ & $\begin{array}{l}0.010^{* *} \\
0.004\end{array}$ \\
\hline in \% of before & $43.3 \%$ & $34.8 \%$ & \\
\hline
\end{tabular}




\section{Table 4. The Effect of Coverage Shocks on Liquidity: Regression Results.}

We relate the log of one plus Amihud's (2002) illiquidity measure to contemporaneous and up to three lags of exogenous shocks to a firm's analyst coverage and to a set of control variables. For variable definitions and details of their construction, see Appendix A. Coverage shocks are coded as indicators set equal to 1 if a firm suffers one or more exogenous coverage terminations during that fiscal quarter. All specifications are estimated using OLS with firm fixed effects, year effects, and a set of fiscal-quarter fixed effects. The fixed effects are not shown for brevity. Standard errors are shown in italics underneath the coefficient estimates. In all columns except column 2, they are clustered at the firm level. In column 2, standard errors are obtained from a bootstrap stratified by quarter with 1,000 replications. We use $* * *$ and $* *$ to denote significance at the $1 \%$ and $5 \%$ level (two-sided), respectively. The number of observations in columns 1 and 2 is 34,256 firm-fiscal quarters for 2,095 treated and 2,095 matched control firms. Due to the presence of lagged shocks, the number of observations in columns 3 and 4 is 31,312 firmfiscal quarters. Column 5 uses a different sample, composed of 9,840 firm-fiscal quarters for 769 treated 'nonguiders' and 769 matched control firms.

\begin{tabular}{|c|c|c|c|c|c|}
\hline & \multicolumn{5}{|c|}{ Dependent variable: log Amihud Illiquidity Measure } \\
\hline & \multicolumn{4}{|c|}{ Estimation sample: Guiders } & \multirow{2}{*}{$\begin{array}{c}\begin{array}{c}\text { Non- } \\
\text { guiders }\end{array} \\
(5)\end{array}$} \\
\hline & $(1)$ & $(2)$ & $(3)$ & (4) & \\
\hline \multicolumn{6}{|l|}{ Exogenous coverage shock } \\
\hline at $t=0$ & $0.008^{* * *}$ & $0.008^{* * *}$ & $0.007^{* * *}$ & $0.007^{* * *}$ & $0.021^{* *}$ \\
\hline & 0.002 & 0.003 & 0.003 & 0.003 & 0.009 \\
\hline at $t=-1$ & & & $-0.009^{* * *}$ & $-0.008^{* *}$ & -0.006 \\
\hline & & & 0.003 & 0.003 & 0.008 \\
\hline at $t=-2$ & & & -0.002 & -0.002 & 0.003 \\
\hline & & & 0.003 & 0.003 & 0.009 \\
\hline at $t=-3$ & & & 0.004 & 0.004 & -0.008 \\
\hline & & & 0.003 & 0.003 & 0.007 \\
\hline$=1$ if multiple coverage shocks & & & & & \\
\hline at $t=0$ & & & & 0.001 & \\
\hline at $t=-1$ & & & & $\begin{array}{c}0.006 \\
-0.023^{\text {*** }} \\
0.007\end{array}$ & \\
\hline Firm characteristics & & & & & \\
\hline $\log$ market cap at $t=-1$ & $-0.103^{* * *}$ & $-0.103^{* * *}$ & $-0.103^{* * *}$ & $-0.103^{* * *}$ & $-0.153^{* * *}$ \\
\hline & 0.008 & 0.005 & 0.008 & 0.008 & 0.020 \\
\hline log coverage at $t=-1$ & $-0.008^{* * *}$ & $-0.008^{* * *}$ & $-0.007^{* * *}$ & $-0.008^{* * *}$ & $-0.010^{* *}$ \\
\hline & 0.002 & 0.001 & 0.002 & 0.002 & 0.004 \\
\hline volatility at $t=-1$ & 0.188 & 0.188 & 0.095 & 0.095 & 0.130 \\
\hline & 0.152 & 0.151 & 0.145 & 0.145 & 0.338 \\
\hline$=1$ if firm is net eq. issuer at $t=-1$ & $-0.019^{* * *}$ & $-0.019^{* * *}$ & $-0.019^{* * *}$ & $-0.019^{* * *}$ & -0.036 \\
\hline & 0.005 & 0.003 & 0.005 & 0.005 & 0.019 \\
\hline Diagnostics & & & & & \\
\hline Within-firm $R^{2}$ & $9.3 \%$ & $9.3 \%$ & $8.9 \%$ & $9.3 \%$ & $9.8 \%$ \\
\hline Wald test: all coefficients $=0$ & $13.5^{* * *}$ & $29.0^{* * * *}$ & $11.9^{* * *}$ & $13.5^{* * *}$ & $5.0^{* * *}$ \\
\hline Number of episodes & 4,190 & 4,190 & 4,190 & 4,190 & 1,538 \\
\hline Number of observations & 34,256 & 34,256 & 31,312 & 31,312 & 9,840 \\
\hline
\end{tabular}


Table 5, Panel A: The Effect of Coverage Shocks on Voluntary Disclosure.

This table tests whether firms respond to an exogenous reduction in analyst coverage by issuing voluntary guidance. We relate one particular form of guidance, management forecasts, to an indicator capturing contemporaneous exogenous coverage terminations along with four leads and four lags. If the coverage shock is truly exogenous, a firm should not be able to anticipate it and so the leads (i.e., shocks that will happen in the future) should be insignificant. The lags are included to allow for persistence in firms' guidance responses to the shocks. For definitions of the control variables and details of their construction, see Appendix A. Columns 1 and 2 are estimated as linear probability models; column 3 is estimated as a conditional (fixed-effect) logit; and column 4 is estimated as a Poisson count model. All specifications include firm fixed effects, year effects, and a set of fiscal-quarter fixed effects. The fixed effects are not shown for brevity. Heteroskedasticity-consistent standard errors are shown in italics underneath the coefficient estimates. They are clustered by firm in columns 1 and 3 and by calendar quarter in column 2. Fixed-effects Poisson models do not permit clustering and so the standard errors in column 4 are White. We use ${ }^{* * *}$ and $* *$ to denote significance at the $1 \%$ and $5 \%$ level (two-sided), respectively. The number of observations in each specification is 34,010 firm-fiscal quarters for 2,095 treated and 2,095 matched control firms.

\begin{tabular}{|c|c|c|c|c|c|}
\hline & & \multicolumn{4}{|c|}{ Dependent variable: } \\
\hline & & \multicolumn{3}{|c|}{$=1$ if management issues forecast } & \multirow{2}{*}{$\begin{array}{c}\text { Number of } \\
\text { forecasts } \\
(4)\end{array}$} \\
\hline & & $(1)$ & $(2)$ & (3) & \\
\hline \multicolumn{6}{|c|}{ Exogenous coverage shock } \\
\hline \multirow[t]{8}{*}{ Leads: } & shock at $t=+4$ & 0.013 & 0.013 & 0.081 & 0.031 \\
\hline & & 0.014 & 0.017 & 0.112 & 0.034 \\
\hline & shock at $t=+3$ & 0.005 & 0.005 & 0.022 & -0.002 \\
\hline & & 0.014 & 0.019 & 0.112 & 0.035 \\
\hline & shock at $t=+2$ & -0.008 & -0.008 & -0.126 & -0.049 \\
\hline & & 0.013 & 0.015 & 0.108 & 0.035 \\
\hline & shock at $t=+1$ & 0.019 & 0.019 & 0.150 & 0.035 \\
\hline & & 0.013 & 0.020 & 0.104 & 0.033 \\
\hline \multirow{2}{*}{\multicolumn{2}{|c|}{ Contemporaneous: shock at $t=0$}} & $0.049^{* * *}$ & $0.049^{* * *}$ & $0.432^{* * *}$ & $0.132^{* * *}$ \\
\hline & & 0.013 & 0.016 & 0.100 & 0.032 \\
\hline \multirow[t]{8}{*}{ Lags: } & shock at $t=-1$ & $0.033^{* *}$ & $0.033^{* *}$ & $0.278^{* * *}$ & $0.081^{* * *}$ \\
\hline & & 0.013 & 0.013 & 0.103 & 0.031 \\
\hline & shock at $t=-2$ & $0.042^{* * *}$ & $0.042^{* *}$ & $0.321^{* * *}$ & $0.107^{* * *}$ \\
\hline & & 0.013 & 0.018 & 0.097 & 0.030 \\
\hline & shock at $t=-3$ & $0.036^{* * *}$ & $0.036^{* *}$ & $0.252^{* * *}$ & $0.076^{* * *}$ \\
\hline & & 0.013 & 0.016 & 0.097 & 0.029 \\
\hline & shock at $t=-4$ & 0.016 & 0.016 & 0.097 & 0.029 \\
\hline & & 0.013 & 0.016 & 0.100 & 0.031 \\
\hline \multicolumn{6}{|c|}{ Firm characteristics } \\
\hline \multirow{2}{*}{\multicolumn{2}{|c|}{$\log$ market cap at $t=-1$}} & $0.064^{* * *}$ & $0.064^{* * *}$ & $0.625^{* * *}$ & $0.291^{* * *}$ \\
\hline & & 0.007 & 0.009 & 0.063 & 0.025 \\
\hline \multirow{2}{*}{\multicolumn{2}{|c|}{ log coverage at $t=-1$}} & 0.001 & 0.001 & 0.012 & 0.001 \\
\hline & & 0.004 & 0.005 & 0.035 & 0.011 \\
\hline \multirow{2}{*}{\multicolumn{2}{|c|}{ volatility at $t=-1$}} & -0.195 & -0.195 & -0.024 & $-0.016^{* *}$ \\
\hline & & 0.158 & 0.183 & 0.015 & 0.007 \\
\hline \multirow{2}{*}{\multicolumn{2}{|c|}{$=1$ if firm is net equity issuer at $t=-1$}} & 0.000 & 0.000 & -0.006 & -0.004 \\
\hline & & 0.009 & 0.007 & 0.082 & 0.026 \\
\hline \multicolumn{6}{|c|}{ Diagnostics } \\
\hline$R^{2}$ & & $49.7 \%$ & $49.7 \%$ & $4.4 \%$ & n.a. \\
\hline Wald te & ficients $=0$ & $10.3^{* * *}$ & $51.5^{* * *}$ & $12.4^{* * *}$ & $18.3^{* * *}$ \\
\hline Estimat & & $\mathrm{OLS} / \mathrm{FE}$ & $\mathrm{OLS} / \mathrm{FE}$ & Logit/FE & Poisson/FE \\
\hline Standar & stered on: & gvkey & quarter & gvkey & robust \\
\hline
\end{tabular}


Table 5, Panel B: The Effect of Coverage Shocks on Voluntary Disclosure by Type of Guidance.

This table relates eight separate measures of voluntary guidance to an indicator capturing contemporaneous exogenous coverage terminations along with three lags. For variable definitions and details of their construction, see Appendix A. All specifications are estimated as linear probability models with firm fixed effects, year effects, and a set of fiscal-quarter fixed effects. The fixed effects are not shown for brevity. Heteroskedasticity-consistent standard errors clustered at the firm level are shown in italics underneath the coefficient estimates. We use $* * *$ and $* *$ to denote significance at the $1 \%$ and $5 \%$ level (two-sided), respectively. The number of observations in each specification is 31,312 firm-fiscal quarters for 2,095 treated and 2,095 matched control firms.

\begin{tabular}{|c|c|c|c|c|c|c|c|c|}
\hline \multirow[b]{2}{*}{$\begin{array}{l}\text { Dependent variable }=1 \\
\text { if management issues ... }\end{array}$} & \multicolumn{3}{|c|}{ Guidance horizon } & \multicolumn{2}{|c|}{ Form of guidance } & \multicolumn{3}{|c|}{ Content of guidance } \\
\hline & $\begin{array}{c}\text { Forecast } \\
(1) \\
\end{array}$ & $\begin{array}{c}\text { Pre- } \\
\text { announce- } \\
\text { ment } \\
(2)\end{array}$ & $\begin{array}{l}\text { Both } \\
(3)\end{array}$ & $\begin{array}{l}\text { Quanti- } \\
\text { tative } \\
\text { guidance } \\
(4) \\
\end{array}$ & $\begin{array}{l}\text { Quali- } \\
\text { tative } \\
\text { guidance } \\
(5)\end{array}$ & $\begin{array}{c}\text { Negative } \\
\text { guidance } \\
(6)\end{array}$ & $\begin{array}{c}\text { Positive } \\
\text { guidance } \\
(7)\end{array}$ & $\begin{array}{l}\text { Hot air } \\
\text { guidance } \\
(8)\end{array}$ \\
\hline \multicolumn{9}{|l|}{ Exogenous coverage shock } \\
\hline \multirow[t]{2}{*}{ at $t=0$} & $0.041^{* * *}$ & 0.002 & $0.036^{* * *}$ & $0.034^{* * *}$ & 0.011 & $0.029^{* * *}$ & 0.013 & 0.007 \\
\hline & 0.009 & 0.007 & 0.009 & 0.010 & 0.006 & 0.009 & 0.007 & 0.006 \\
\hline \multirow[t]{2}{*}{ at $t=-1$} & $0.024^{* * *}$ & -0.001 & $0.020^{* *}$ & $0.020^{* *}$ & 0.010 & 0.014 & 0.008 & -0.003 \\
\hline & 0.009 & 0.006 & 0.009 & 0.009 & 0.006 & 0.009 & 0.007 & 0.007 \\
\hline \multirow[t]{2}{*}{ at $t=-2$} & $0.036^{* * *}$ & -0.003 & $0.026^{* * *}$ & $0.019^{* *}$ & $0.010^{* *}$ & $0.023^{* *}$ & -0.001 & $0.016^{* *}$ \\
\hline & 0.009 & 0.007 & 0.009 & 0.009 & 0.005 & 0.009 & 0.007 & 0.007 \\
\hline \multirow[t]{2}{*}{ at $t=-3$} & $0.033^{* * *}$ & 0.005 & $0.032^{* * *}$ & $0.025^{* * *}$ & 0.008 & 0.008 & $0.017^{* *}$ & 0.009 \\
\hline & 0.009 & 0.008 & 0.010 & 0.010 & 0.006 & 0.009 & 0.008 & 0.007 \\
\hline \multicolumn{9}{|l|}{ Firm characteristics } \\
\hline \multirow[t]{2}{*}{$\log$ market cap at $t=-1$} & $0.059^{* * *}$ & -0.001 & $0.057^{* * *}$ & $0.048^{* * *}$ & $0.011^{* * *}$ & $0.038^{* * *}$ & 0.006 & $0.013^{* * *}$ \\
\hline & 0.007 & 0.006 & 0.008 & 0.007 & 0.004 & 0.006 & 0.005 & 0.004 \\
\hline \multirow[t]{2}{*}{ log coverage at $t=-1$} & 0.000 & 0.000 & 0.002 & 0.009 & $-0.007^{* *}$ & 0.004 & 0.003 & 0.004 \\
\hline & 0.004 & 0.004 & 0.005 & 0.005 & 0.003 & 0.005 & 0.004 & 0.003 \\
\hline \multirow[t]{2}{*}{ volatility at $t=-1$} & -0.252 & -0.236 & $-0.359^{* *}$ & $-0.382^{* *}$ & -0.053 & $-0.352^{* *}$ & -0.110 & -0.091 \\
\hline & 0.150 & 0.130 & 0.177 & 0.165 & 0.100 & 0.138 & 0.118 & 0.086 \\
\hline \multirow[t]{2}{*}{$=1$ if firm is net equity issuer at $t=-1$} & 0.000 & 0.003 & -0.001 & -0.005 & 0.002 & $-0.029^{* * *}$ & $0.018^{* * *}$ & $0.013^{* *}$ \\
\hline & 0.009 & 0.006 & 0.009 & 0.009 & 0.004 & 0.009 & 0.007 & 0.006 \\
\hline \multicolumn{9}{|l|}{ Diagnostics } \\
\hline$R^{2}$ & $49.9 \%$ & $20.1 \%$ & $45.5 \%$ & $46.7 \%$ & $12.1 \%$ & $28.7 \%$ & $16.8 \%$ & $21.6 \%$ \\
\hline Wald test: all coeff. $=0$ & $14.2^{* * *}$ & $3.3^{* * *}$ & $12.3^{* * *}$ & $10.9^{* * *}$ & $4.8^{* * *}$ & $10.3^{* * *}$ & $2.5^{* * *}$ & $4.6^{* * *}$ \\
\hline
\end{tabular}




\section{Table 5, Panel C: The Effect of Different Types of Coverage Shocks on Disclosure.}

This table examines the effect of different types of exogenous coverage terminations on voluntary guidance behavior. Guidance behavior is measured as the probability that management issues a forecast. Coverage shocks are coded as indicators set equal to 1 if a firm suffers one or more exogenous coverage termination that fiscal quarter and additional indicators are included that capture firms suffering multiple shocks in a given quarter (column 1), loss of a local analyst (columns 2 through 4 ), loss of an institutionsonly broker (column 5), or particularly 'severe' shocks (columns 6 through 8). Severity is measured using $\triangle A I M$, the change in a firm's Amihud illiquidity measure around the coverage shock relative to the contemporaneous change experienced by its matched control. For variable definitions and details of their construction, see Appendix A. All specifications are estimated as linear probability models with firm and year effects and a set of fiscal-quarter fixed effects (not shown for brevity). Heteroskedasticity-consistent standard errors clustered at the firm level are shown in italics underneath the coefficient estimates. We use ***,**, and * to denote significance at the $1 \%, 5 \%$, and $10 \%$ level (two-sided), respectively. The number of observations in each specification is 31,312 firm-fiscal quarters for 2,095 treated and 2,095 matched control firms.

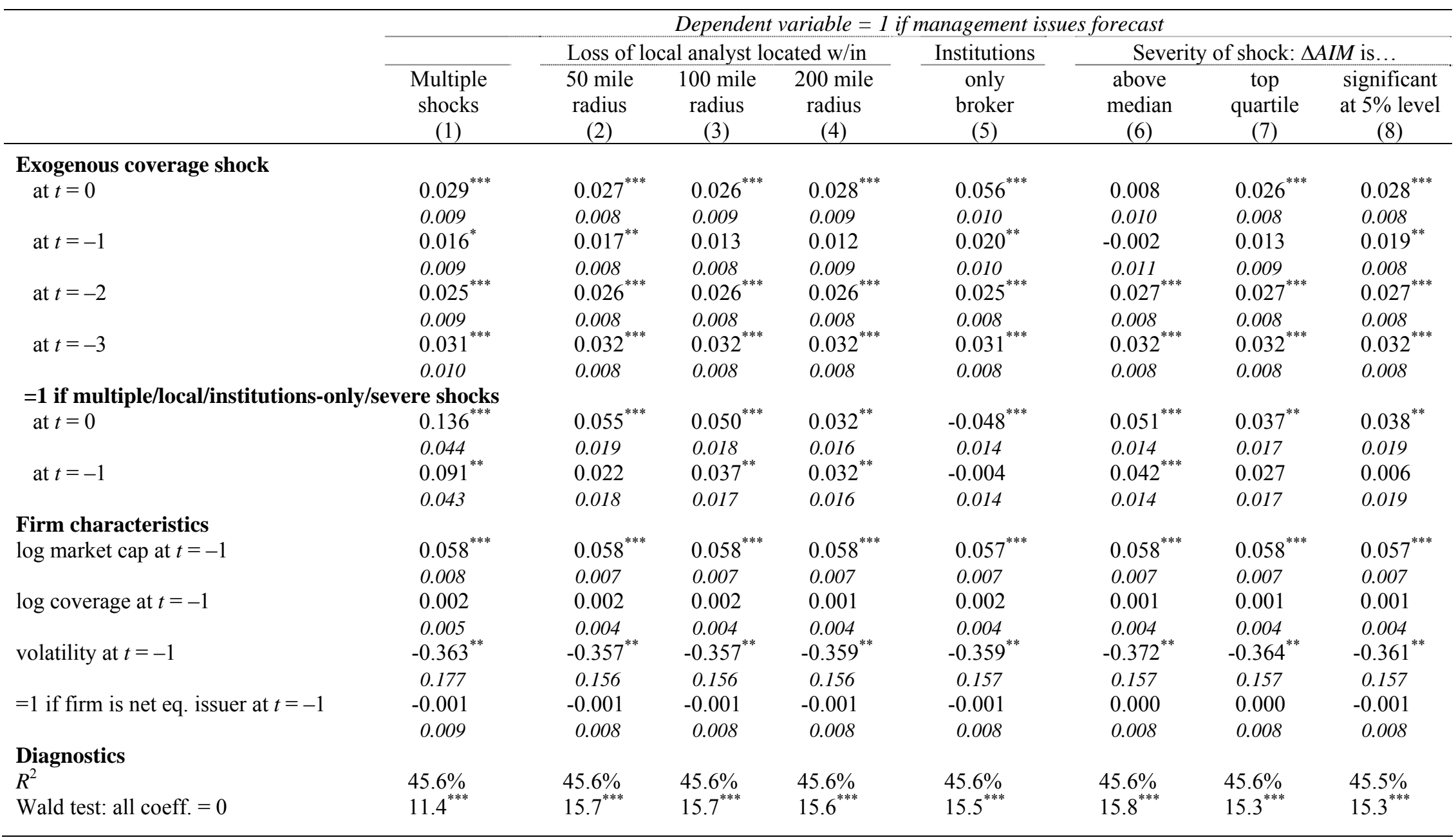




\section{Table 6. Naïve Regressions of Liquidity on Voluntary Guidance.}

We relate the log of one plus Amihud's (2002) illiquidity measure to eight separate measures of voluntary guidance and to a set of control variables. For variable definitions and details of their construction, see Appendix A. All specifications are estimated using OLS with firm fixed effects, year effects, and a set of fiscalquarter fixed effects. The fixed effects are not shown for brevity. Heteroskedasticity-consistent standard errors clustered at the firm level are shown in italics underneath the coefficient estimates. We test for first-order serial correlation in the dependent variable using the modified Durbin-Watson test developed for panel-data models by Bhargava, Franzini, and Narendranathan (1982). The critical value at the $5 \%$ level for panels of our size is 1.96 . We use *** and $* *$ to denote significance at the $1 \%$ and $5 \%$ level (two-sided), respectively. The number of observations is 34,256 firm-fiscal quarters for 2,095 treated and 2,095 matched control firms.

\begin{tabular}{|c|c|c|c|c|c|c|c|c|c|}
\hline & \multicolumn{9}{|c|}{ Dependent variable: log Amihud Illiquidity Measure } \\
\hline & \multicolumn{4}{|c|}{ Guidance horizon } & \multicolumn{2}{|c|}{ Form of guidance } & \multicolumn{3}{|c|}{ Content of guidance } \\
\hline & $\begin{array}{c}\text { Forecast } \\
(1)\end{array}$ & $\begin{array}{c}\text { Forecast } \\
(2)\end{array}$ & $\begin{array}{c}\text { Pre- } \\
\text { announce } \\
\text { ment } \\
(3)\end{array}$ & $\begin{array}{c}\text { Both } \\
(4)\end{array}$ & $\begin{array}{c}\text { Quanti- } \\
\text { tative } \\
(5)\end{array}$ & $\begin{array}{c}\text { Quali- } \\
\text { tative } \\
(6)\end{array}$ & $\begin{array}{l}\text { Negative } \\
(7)\end{array}$ & $\begin{array}{c}\text { Positive } \\
(8)\end{array}$ & $\begin{array}{l}\text { Hot air } \\
(9)\end{array}$ \\
\hline Voluntary guidance & & & & & & & & & \\
\hline$=1$ if firm issues $\ldots$ guidance at $t=0$ & $\begin{array}{r}-0.004 \\
0.003\end{array}$ & & & & & & & & \\
\hline$=1$ if firm issues $\ldots$ guidance at $t=-1$ & $\begin{array}{l}-0.010^{* * *} \\
0.003\end{array}$ & $\begin{array}{l}-0.010^{* * *} \\
0.003\end{array}$ & $\begin{array}{r}-0.007 \\
0.004\end{array}$ & $\begin{array}{l}-0.011^{* * *} \\
0.003\end{array}$ & $\begin{array}{l}-0.010^{* * *} \\
0.002\end{array}$ & $\begin{array}{c}-0.012^{* *} \\
0.006\end{array}$ & $\begin{array}{l}-0.012^{* * *} \\
0.002\end{array}$ & $\begin{array}{r}-0.001 \\
0.003\end{array}$ & $\begin{array}{r}-0.001 \\
0.002\end{array}$ \\
\hline Firm characteristics & & & & & & & & & \\
\hline $\log$ market cap at $t=-1$ & $\begin{array}{l}-0.102^{* * *} \\
0.009\end{array}$ & $\begin{array}{l}-0.102^{* * *} \\
0.008\end{array}$ & $\begin{array}{l}-0.103^{* * *} \\
0.008\end{array}$ & $\begin{array}{l}-0.103^{* * *} \\
0.008\end{array}$ & $\begin{array}{l}-0.103^{* * *} \\
0.008\end{array}$ & $\begin{array}{l}-0.103^{* * *} \\
0.008\end{array}$ & $\begin{array}{l}-0.103^{* * *} \\
0.008\end{array}$ & $\begin{array}{c}-0.103^{* * *} \\
0.008\end{array}$ & $\begin{array}{c}-0.103^{* * *} \\
0.008\end{array}$ \\
\hline log coverage at $t=-1$ & $\begin{array}{c}-0.007^{* *} \\
0.003\end{array}$ & $\begin{array}{c}-0.007^{* * *} \\
0.002\end{array}$ & $\begin{array}{c}-0.007^{* * *} \\
0.002\end{array}$ & $\begin{array}{c}-0.007^{* * *} \\
0.001\end{array}$ & $\begin{array}{c}-0.007^{* * *} \\
0.002\end{array}$ & $\begin{array}{c}-0.007^{* * *} \\
0.002\end{array}$ & $\begin{array}{c}-0.007^{* * *} \\
0.002\end{array}$ & $\begin{array}{c}-0.008^{* * *} \\
0.002\end{array}$ & $\begin{array}{c}-0.008^{* * *} \\
0.002\end{array}$ \\
\hline volatility at $t=-1$ & $\begin{array}{l}0.199 \\
0.221\end{array}$ & $\begin{array}{l}0.200 \\
0.153\end{array}$ & $\begin{array}{l}0.188 \\
0.152\end{array}$ & $\begin{array}{l}0.200 \\
0.153\end{array}$ & $\begin{array}{l}0.196 \\
0.152\end{array}$ & $\begin{array}{l}0.193 \\
0.153\end{array}$ & $\begin{array}{l}0.196 \\
0.152\end{array}$ & $\begin{array}{l}0.189 \\
0.152\end{array}$ & $\begin{array}{l}0.189 \\
0.152\end{array}$ \\
\hline$=1$ if firm is net equity issuer at $t=-1$ & $\begin{array}{c}-0.019^{* * *} \\
0.004\end{array}$ & $\begin{array}{c}-0.020^{* * *} \\
0.005\end{array}$ & $\begin{array}{c}-0.019^{* * *} \\
0.005\end{array}$ & $\begin{array}{c}-0.019^{* * *} \\
0.005\end{array}$ & $\begin{array}{c}-0.020^{* * *} \\
0.005\end{array}$ & $\begin{array}{c}-0.019^{* * *} \\
0.005\end{array}$ & $\begin{array}{c}-0.020^{* * *} \\
0.005\end{array}$ & $\begin{array}{c}-0.019^{* * *} \\
0.005\end{array}$ & $\begin{array}{c}-0.019^{* * *} \\
0.005\end{array}$ \\
\hline Diagnostics & & & & & & & & & \\
\hline $\begin{array}{l}\text { Within-firm } R^{2} \\
\text { Wald test: all coeff. }=0\end{array}$ & $\begin{array}{c}9.3 \% \\
12.9^{* * *}\end{array}$ & $\begin{array}{c}9.3 \% \\
13.4^{* * *}\end{array}$ & $\begin{array}{r}9.3 \% \\
13.4^{* * *}\end{array}$ & $\begin{array}{r}9.3 \% \\
13.4^{* * *}\end{array}$ & $\begin{array}{c}9.3 \% \\
13.5^{* * *}\end{array}$ & $\begin{array}{r}9.3 \% \\
13.4^{* * *}\end{array}$ & $\begin{array}{c}9.4 \% \\
13.4^{* * *}\end{array}$ & $\begin{array}{r}9.3 \% \\
13.5^{* * *}\end{array}$ & $\begin{array}{r}9.3 \% \\
13.9^{* * *}\end{array}$ \\
\hline Durbin-Watson test for serial corr. & 0.9 & 0.9 & 0.9 & 0.9 & 0.9 & 0.9 & 0.9 & 0.9 & 0.9 \\
\hline
\end{tabular}




\section{Table 7. Causal Effect of Voluntary Disclosure on Liquidity.}

We estimate the causal effect of voluntary disclosure at $t=0$ on liquidity at $t=+1$ for four guidance choices using exogenous shocks to a firm's analyst coverage as an instrument. Specifically, we instrument a firm's guidance choice in quarter $t=0$ with a set of indicator variables capturing exogenous coverage terminations in quarters $t=-3$ to $t=0$. (See Table 5, Panel B for the corresponding first-stage estimates.) The identifying assumption is that exogenous coverage terminations dated -3 to 0 do not affect liquidity in quarter $t=+1$ other than through their effect on the firm's guidance choice. (See Table 4 for the corresponding reduced-form estimates.) We focus on the four guidance choices that, according to the first-stage estimates in Table 5, Panel $\mathrm{B}$, respond significantly to the instrument. For variable definitions and details of their construction, see Appendix A. All specifications are estimated using OLS with firm fixed effects, year effects, and a set of fiscal-quarter fixed effects. The fixed effects are not shown for brevity. Heteroskedasticity-consistent standard errors clustered at the firm level are shown in italics underneath the coefficient estimates. We use $* * *$ and $* *$ to denote significance at the $1 \%$ and $5 \%$ level (twosided), respectively. The Staiger-Stock (1997) test is a Wald test of weak instruments, i.e., of the extent of correlation between the guidance choice and the instrument. It has a critical value of $10 \mathrm{in}$ an $F$-test. The number of observations in each specification is 27,870 firm-fiscal quarters for 2,095 treated and 2,095 matched control firms. (The lower number of observations compared to Table 5, Panel B reflects the fact that the first stage is lagged relative to the second stage.)

\begin{tabular}{|c|c|c|c|c|}
\hline & \multicolumn{4}{|c|}{$\begin{array}{c}\text { Dependent variable: } \\
\log \text { Amihud Illiquidity Measure at } t=+1\end{array}$} \\
\hline & $\begin{array}{c}\text { Forecast } \\
\quad(1)\end{array}$ & $\begin{array}{l}\text { Forecast } \\
\text { or pre- } \\
\text { announce- } \\
\text { ment } \\
(2)\end{array}$ & $\begin{array}{l}\text { Quanti- } \\
\text { tative } \\
\text { (3) }\end{array}$ & $\begin{array}{l}\text { Negative } \\
(4)\end{array}$ \\
\hline \multicolumn{5}{|l|}{ Instrumented voluntary guidance } \\
\hline & 0.035 & 0.037 & 0.039 & 0.044 \\
\hline \multicolumn{5}{|l|}{ Firm characteristics } \\
\hline $\log$ market cap at $t=0$ & $\begin{array}{l}-0.101^{* * *} \\
0.008\end{array}$ & $\begin{array}{l}-0.101^{* * *} \\
0.008\end{array}$ & $\begin{array}{l}-0.101^{* * *} \\
0.008\end{array}$ & $\begin{array}{c}-0.100^{* * *} \\
0.008\end{array}$ \\
\hline log coverage at $t=0$ & $\begin{array}{l}-0.005^{* * *} \\
0.002\end{array}$ & $\begin{array}{l}-0.005^{* * *} \\
0.002\end{array}$ & $\begin{array}{l}-0.005^{* * *} \\
0.002\end{array}$ & $\begin{array}{l}-0.005^{* * *} \\
0.002\end{array}$ \\
\hline volatility at $t=0$ & 0.089 & 0.090 & 0.088 & 0.078 \\
\hline$=1$ if firm is net equity issuer at $t=0$ & $\begin{array}{l}0.158 \\
-0.018^{* * *} \\
0.005\end{array}$ & $\begin{array}{l}0.158 \\
-0.018^{* * *} \\
0.005\end{array}$ & $\begin{array}{l}0.158 \\
-0.018^{* * *} \\
0.005\end{array}$ & $\begin{array}{l}0.158 \\
-0.020^{* * *} \\
0.006\end{array}$ \\
\hline Diagnostics & & & & \\
\hline Within-firm $R^{2}$ & $8.5 \%$ & $8.5 \%$ & $8.5 \%$ & $8.5 \%$ \\
\hline Wald test: all coeff. $=0$ & $12.2^{* * *}$ & $12.2^{* * *}$ & $12.3^{* * *}$ & $12.3^{* * *}$ \\
\hline Staiger-Stock test $(F)$ & $30.8^{* * *}$ & $20.8^{* * *}$ & $15.9^{* * *}$ & $10.1^{* * *}$ \\
\hline
\end{tabular}




\section{Table 8. Causal Effect of Voluntary Disclosure on Bid-Ask Spreads.}

This table repeats the analysis of Table 7 using bid-ask spreads to proxy for liquidity. Quarterly average spreads are computed as $100 *$ (ask-bid)/[(ask+bid)/2] using daily closing bid and ask data from CRSP. As in Table 7, we estimate the causal effect of voluntary disclosure at $t=0$ on liquidity at $t=+1$ for four guidance choices using exogenous shocks to a firm's analyst coverage as an instrument. Specifically, we instrument a firm's guidance choice in quarter $t=0$ with a set of indicator variables capturing exogenous coverage terminations in quarters $t=-3$ to $t=0$. (See Table 5, Panel B for the corresponding first-stage estimates.) The identifying assumption is that exogenous coverage terminations dated -3 to 0 do not affect liquidity in quarter $t=+1$ other than through their effect on the firm's guidance choice. We focus on the four guidance choices that, according to the first-stage estimates in Table 5, Panel B, respond significantly to the instrument. For variable definitions and details of their construction, see Appendix A. All specifications are estimated using OLS with firm fixed effects, year effects, and a set of fiscalquarter fixed effects. The fixed effects are not shown for brevity. Heteroskedasticity-consistent standard errors clustered at the firm level are shown in italics underneath the coefficient estimates. We use $* * *$ and $* *$ to denote significance at the $1 \%$ and $5 \%$ level (two-sided), respectively. The Staiger-Stock (1997) test is a Wald test of weak instruments, i.e., of the extent of correlation between the guidance choice and the instrument. It has a critical value of 10 in an $F$-test. Due to a few missing bid-ask spreads, the number of observations in each specification is 27,441 firm-fiscal quarters for 2,095 treated and 2,095 matched control firms.

\begin{tabular}{|c|c|c|c|c|}
\hline & \multicolumn{4}{|c|}{ Dependent variable: Bid-ask spreads at $t=+1$} \\
\hline & $\begin{array}{c}\text { Forecast } \\
(1)\end{array}$ & $\begin{array}{l}\text { Forecast } \\
\text { or pre- } \\
\text { announce- } \\
\text { ment } \\
(2)\end{array}$ & $\begin{array}{l}\text { Quanti- } \\
\text { tative } \\
\text { (3) }\end{array}$ & $\begin{array}{c}\text { Negative } \\
\text { (4) }\end{array}$ \\
\hline \multirow[t]{2}{*}{$\begin{array}{l}\text { Instrumented voluntary guidance } \\
\text { guidance choice at } t=0\end{array}$} & $-0.033^{* * *}$ & $-0.032^{* * *}$ & $-0.037^{* * *}$ & 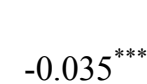 \\
\hline & 0.003 & 0.003 & 0.003 & 0.003 \\
\hline \multicolumn{5}{|l|}{ Firm characteristics } \\
\hline \multirow{2}{*}{$\log$ market cap at $t=0$} & $-0.488^{* * *}$ & $-0.486^{* * *}$ & $-0.494^{* * *}$ & $-0.514^{* * *}$ \\
\hline & 0.000 & 0.000 & 0.000 & 0.000 \\
\hline \multirow[t]{2}{*}{ log coverage at $t=0$} & $-0.023^{* *}$ & $-0.023^{* *}$ & $-0.024^{* *}$ & $-0.027^{* * *}$ \\
\hline & 0.000 & 0.000 & 0.000 & 0.000 \\
\hline \multirow[t]{2}{*}{ volatility at $t=0$} & $0.032^{* * *}$ & $0.033^{* * *}$ & $0.032^{* * *}$ & $0.031^{* * *}$ \\
\hline & 0.008 & 0.008 & 0.008 & 0.008 \\
\hline \multirow[t]{2}{*}{$=1$ if firm is net equity issuer at $t=0$} & $-0.001^{* * *}$ & $-0.001^{* * *}$ & $-0.001^{* * *}$ & $-0.001^{* * *}$ \\
\hline & 0.0003 & 0.0002 & 0.0003 & 0.0003 \\
\hline \multicolumn{5}{|l|}{ Diagnostics } \\
\hline Within-firm $R^{2}$ & $13.0 \%$ & $12.9 \%$ & $13.2 \%$ & $12.7 \%$ \\
\hline Wald test: all coeff. $=0$ & $62.5^{* * *}$ & $62.2^{* * *}$ & $62.5^{* * *}$ & $62.4^{* * *}$ \\
\hline Staiger-Stock test $(F)$ & $30.8^{* * *}$ & $20.8^{* * *}$ & $15.9^{* * *}$ & $10.1^{* * *}$ \\
\hline
\end{tabular}

